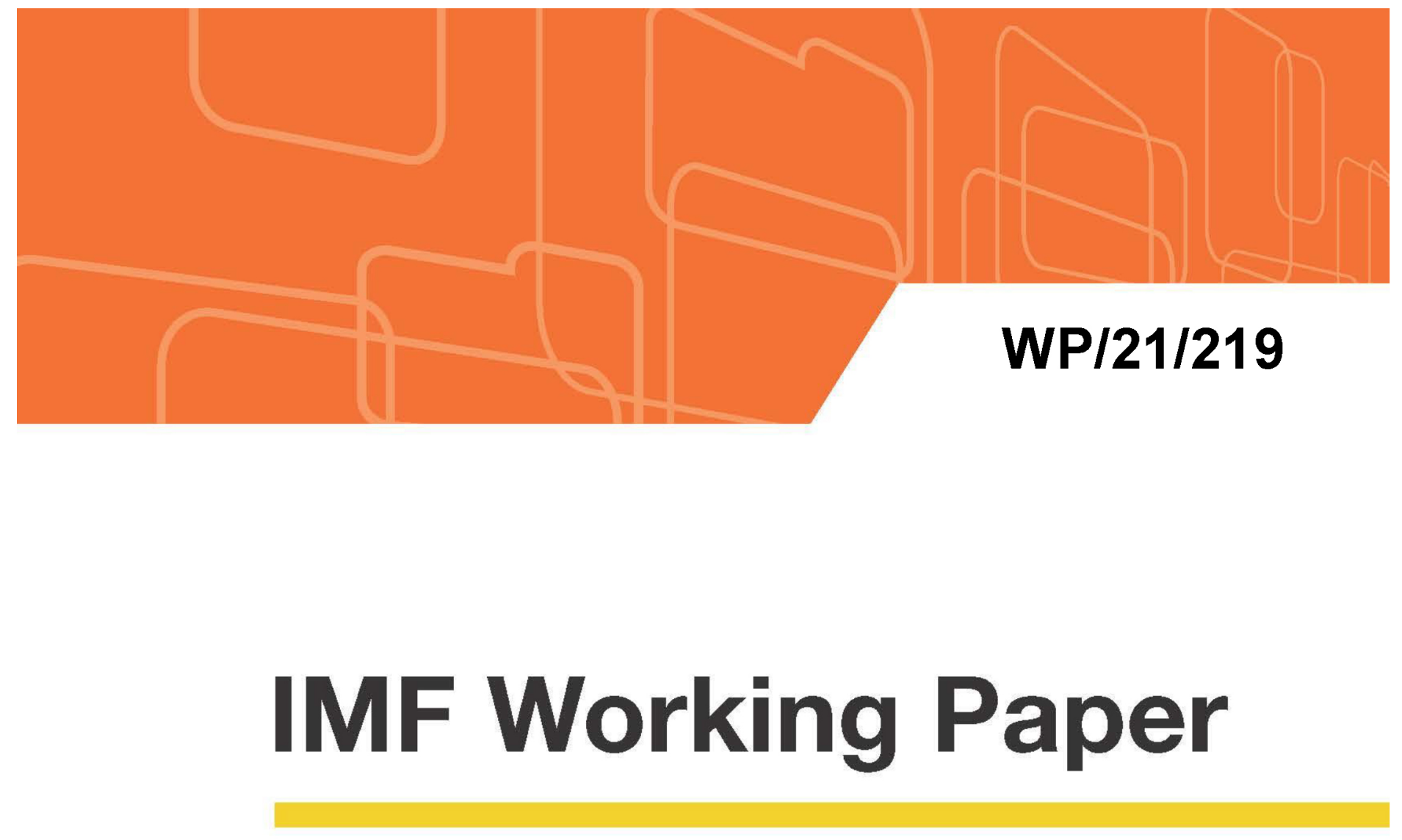

\title{
Stock Returns and Inflation Redux: An Explanation from Monetary Policy in Advanced and Emerging Markets
}

\author{
by Zhongxia Zhang
}

IMF Working Papers describe research in progress by the author(s) and are published to elicit comments and to encourage debate. The views expressed in IMF Working Papers are those of the author(s) and do not necessarily represent the views of the IMF, its Executive Board, or IMF management. 


\title{
IMF Working Paper
}

European Department

\section{Stock Returns and Inflation Redux: An Explanation from Monetary Policy in Advanced and Emerging Markets}

\section{Prepared by Zhongxia Zhang}

Authorized for distribution by Rachel van Elkan

August 2021

IMF Working Papers describe research in progress by the author(s) and are published to elicit comments and to encourage debate. The views expressed in IMF Working Papers are those of the author(s) and do not necessarily represent the views of the IMF, its Executive Board, or IMF management.

\begin{abstract}
Classical theories of monetary economics predict that real stock returns are negatively correlated with inflation when monetary policy is countercyclical. Previous empirical studies mostly focus on a small group of developed countries or a few countries with hyperinflation. In this paper, I examine the stock return-inflation relation under different monetary policy regimes and conditions using an expanded dataset of 71 economies. Empirical evidence suggests that the stock return-inflation relation is partially driven by monetary policy. If a country's monetary authority conducts a more countercyclical monetary policy, the stock return-inflation relation becomes more negative. In addition, the results differ by monetary policy framework. In exchange rate anchor countries, stock markets do not respond to monetary policy cyclicality. In inflation targeting countries, stock markets react more strongly to inflation. A key contribution of this paper is to classify inflation targeters by their behaviors, and illustrate that behavior matters in shaping market perceptions: markets react to inflation and monetary policy cyclicality when central banks are able to control inflation within their target bands. In this case markets are sensitive to inflation dynamics when inflation is above the announced target bands. Finally, when monetary policy is constrained by the Zero Lower Bound (ZLB), a structural break is introduced and real stock returns no longer respond to inflation and monetary policy cyclicality.
\end{abstract}

JEL Classification Numbers: G12, E31, E52.

Keywords: Stock Return, Inflation, Monetary Policy.

Author's E-Mail Address: zzhang2@,imf.org 


\title{
Stock Returns and Inflation Redux: An Explanation from Monetary Policy in Advanced and Emerging Markets*
}

\author{
Zhongxia Zhang \\ International Monetary Fund
}

August 4, 2021

\begin{abstract}
Classical theories of monetary economics predict that real stock returns are negatively correlated with inflation when monetary policy is countercyclical. Previous empirical studies mostly focus on a small group of developed countries or a few countries with hyperinflation. In this paper, I examine the stock return-inflation relation under different monetary policy regimes and conditions using an expanded dataset of 71 economies. Empirical evidence suggests that the stock return-inflation relation is partially driven by monetary policy. If a country's monetary authority conducts a more countercyclical monetary policy, the stock return-inflation relation becomes more negative. In addition, the results differ by monetary policy framework. In exchange rate anchor countries, stock markets do not respond to monetary policy

*Zhang: European Department, International Monetary Fund, 700 19th Street, N.W., Washington, D.C. 20431 (email: zzhang2@imf.org). I am grateful to Jay Shambaugh, Graciela Kaminsky, Tara Sinclair, Chao Wei, Michael Bradley, Pamela Labadie, Frederick Joutz, Robert Phillips, Valerie Ramey, Carl Walsh, Aart Kraay, Tamim Bayoumi, Rachel van Elkan, Xingwei Hu, Evridiki Tsounta, Dong Wu, Xin Xu, Peichu Xie, Dun Jia, and participants at the 2018 Asian Meeting of the Econometric Society, IMF EUR seminar, GWU Macro-International seminar, 3rd international Workshop on Financial Markets and Nonlinear Dynamics, 22nd EBES Conference, Workshop on Financial Econometrics and Empirical Modeling of Financial Markets, 43rd EEA Annual Conference for their valuable comments. The views expressed in this paper are those of the author. All errors are my own.
\end{abstract}


cyclicality. In inflation targeting countries, stock markets react more strongly to inflation. A key contribution of this paper is to classify inflation targeters by their behaviors, and illustrate that behavior matters in shaping market perceptions: markets react to inflation and monetary policy cyclicality when central banks are able to control inflation within their target bands. In this case, markets are sensitive to inflation dynamics when inflation is above the announced target bands. Finally, when monetary policy is constrained by the Zero Lower Bound (ZLB), a structural break is introduced and real stock returns no longer respond to inflation and monetary policy cyclicality.

JEL Classification: G12, E31, E52.

Keywords: Stock Return, Inflation, Monetary Policy. 


\section{Introduction}

The subject of stock returns and inflation enjoys a decades-long research history. Academic interests in this topic have waxed and waned with the importance of inflation on the macroeconomy. The high inflation episodes in the 1970s have imposed heavy costs on living standards and economic stability. Stock returns were dismal during this period, which in turn sparked extensive studies in stock returns and inflation. The COVID-19 pandemic has triggered renewed interest in the relationship between stock returns and inflation. To mitigate the impact of the pandemic, central banks and finance ministries around the world have taken unprecedented policy actions. While such actions were pivotal in preventing a free fall of the world economy and supporting a robust recovery, there could be side effects such as asset bubbles and widening inequality. As Consumer Price Indices rebound strongly in many parts of the world, concerns arise on whether the pick-up in inflation is temporary or permanent and the associated implications for the financial markets.

The topic of stock returns and inflation covers a joint research area of finance and macroeconomics. For financial economists, the relationship between stock returns and inflation quantifies the extent to which stocks can hedge against inflation risk. It is important for trading and risk management purposes. Monetary economists are keen to understand whether inflation and monetary policy have any effect on stock returns. The stock market is a primary source of direct financing for firms, and stock price fluctuations affect real economic activity and financial stability, including corporate borrowing and investment decisions (Baker et al., 2003; Pastor and Veronesi, 2003), and household consumption and saving decisions induced by changes in net worth. Therefore, central banks that aim at stabilizing prices have to take into account the effects of inflation on asset returns.

Historically, real stock prices decline when inflation rises in developed countries. Equity shares, which are claims on future output of firms, do not prove to be a good hedge against inflation risk as researchers find a negative correlation between real stock return and inflation in the short run in developed countries. This phenomenon has intrigued the economics profession to investigate why inflation as a nominal variable has an impact on real stock prices or the real value of claims on physical assets.

Among various theories to explain the negative stock return-inflation correlation, 
existing hypotheses in monetary economics assert that the negative relationship is a result of central bank's countercyclical policy reaction: when inflation rises, a central bank that aims to maintain price stability and conducts countercyclical monetary policy will lift its policy rate. Therefore, changes in inflation affect real interest rates. As the stock price is equal to the current value of all future cash flows, an increase in interest rate (discount rate) lowers the net present value of stocks. In addition, higher interest rates lead to larger borrowing costs for firms, increase the attractiveness of competing assets such as bonds and deposits, dry up liquidity in the stock market, and put downward pressures on stock returns.

Previous work on this issue mostly focuses on either one country (Fama, 1981), a small group of industrialized countries, with just a few studies focusing on emerging markets (Spyrou, 2004; Gultekin, 1983 and Erb et al., 1995 are exceptions), despite the rising importance of emerging markets (Cubeddu et al., 2014). Gultekin (1983) investigates stock returns and inflation in 26 countries for the postwar period, and Erb et al. (1995) study stock returns and inflation in 41 developed and emerging equity markets over 22 years. These studies appear less representative given the rapidly changing developments in the international monetary and financial system, especially the rise of emerging market economies, as well as inflation developments from previous hyperinflation concerns have been superseded by the subsequent deflation risk. Indeed, in recent years, policymakers and investors are increasingly wary of stock market spillover effects from emerging markets to the rest of the world, while more emerging markets' central banks are moving towards inflation targeting regimes.

This paper aims to revisit the important policy question of how monetary policy affects the way stock returns react to inflation. In this paper, I expand the research to a quarterly panel dataset of 71 advanced and emerging economies over a period of 35 years. This dataset contains not only rich information on stock returns and inflation, but also substantial variations of other macroeconomic variables and financial indicators. It makes comparisons among countries and across several monetary policy dimensions possible. This paper dissects monetary policy into different regimes and conditions to understand its role on stock returns and inflation (Figure 1). It focuses on three key elements of monetary policy: monetary policy cyclicality, monetary policy framework and monetary policy flexibility. Doing so can show a comprehensive picture of the effectiveness of monetary policy in driving the stock return-inflation 


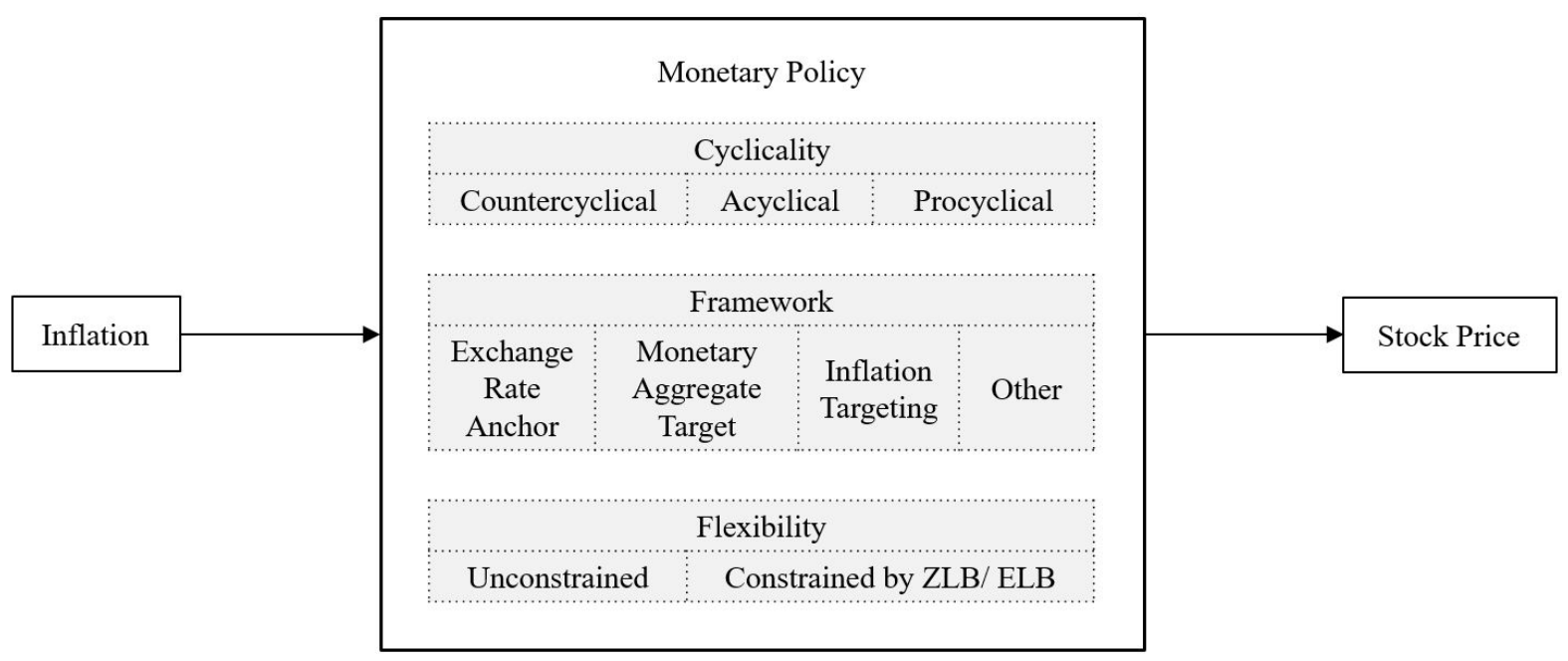

Figure 1: Key Monetary Policy Elements that Affect Stock Returns and Inflation

relations. To the best of my knowledge, this is the first paper that studies stock returns and inflation, tests hypotheses of monetary policy cyclicality in the literature, and documents differences between the advanced and emerging markets from such a broad set of countries. It examines the outcomes of monetary policy frameworks with an emphasis on inflation targeters' behaviors, as well as the Zero Lower Bound.

I first examine the stock return-inflation relationship based on monetary policy cyclicality. I augment the panel regressions by including monetary policy cyclicality measures and a monetary aggregate factor. To address the econometric issues of serial correlation, heteroskedasticity, and cross-sectional dependence, I apply the DriscollKraay standard error estimators. By testing an existing hypothesis in the literature, results confirm that monetary policy cyclicality can partly explain why stock markets respond differently to inflation. Results indicate that real stock returns decline when inflation increases, with larger reactions to inflation in advanced markets than emerging markets. The differences between advanced and emerging markets are interesting but they have not been highlighted enough in the literature before. They imply that practitioners and policymakers in emerging markets should use caution when borrowing the experience from advanced markets. Moreover, if a country pursues a more countercyclical monetary policy, stock markets will react more negatively to inflation.

I then study the stock return-inflation relationship across monetary policy frameworks. Under an exchange rate anchor regime, real stock returns do not pay attention 
to the monetary policy cyclicality. In contrast, under an inflation targeting regime, real stock returns react extremely negatively to inflation, compared to the baseline findings. When central banks have the capacity to control inflation within their announced target bands, markets are sensitive to inflation dynamics when inflation is above the target band. I show that inflation targeting countries exhibit a large degree of heterogeneity regarding the amount of time inflation stays within the central bank's target bands. And stock markets do differentiate behavior by reacting differently to inflation and monetary policy cyclicality.

Finally, I analyze the role of monetary policy flexibility on stock return and inflation. When the policy rate is constrained by the Zero Lower Bound, a structural break is revealed and markets disregard inflation and monetary policy cyclicality. The results illustrate how limited monetary policy flexibility alters the way stock returns react to inflation.

The remainder of the paper is organized as follows: Section 2 provides a brief and selective literature review on previous studies. Section 3 documents the underlying data and presents some key stylized facts. Section 4 describes the analytical framework and displays the main results from panel regressions. It examines the role of monetary policy by testing an existing hypothesis in the literature. It also runs augmented regressions and shows how monetary policy cyclicality shapes the stock return-inflation relation. Different monetary policy frameworks and the outcome of Zero Lower Bound are also studied. Section 5 performs several robustness checks. Section 6 discusses policy implications, possible avenues for future research, and concludes.

\section{Literature Review}

It is empirically well documented in the literature that nominal stock returns react negatively to inflation in the United States and several industrialized countries (Lintner, 1975; Fama and Schwert, 1977; Fama, 1981). This is a long-standing phenomenon that has attracted economists' attention, because people do not expect real stock return is affected by a nominal variable such as inflation. According to the classical view of Irving Fisher (1930), expected nominal return on an asset should equal 
the expected real return plus expected inflation. Therefore, stocks, which represent claims on real output of firms, should be a good hedge against both expected and unexpected inflation. In the "best of all possible worlds", one should observe that the nominal interest rate co- move in a one-to-one relationship with inflation if the real interest rate is constant in the short term.

Research on the stock return-inflation relation from an international perspective produce similar findings. Gultekin (1983) investigates the relation between common stock returns and inflation in 26 countries for the postwar period, and shows that the results do not support the Fisher Hypothesis. Erb et al. (1995) study inflation and stock returns in 41 developed and emerging equity markets over 22 years and document a significant negative relation for most countries.

The empirical anomaly has sparked a number of hypotheses attempting to explain the phenomenon, most notably the inflation illusion hypothesis (Modigliani and Cohn, 1979; Campbell and Vuolteenaho, 2004), the proxy hypothesis (Fama, 1981), the tax hypothesis (Feldstein, 1980), the time-varying risk aversion hypothesis (Brandt and Wang, 2003), and the sticky discount rate hypothesis (Katz et al., 2017). The inflation illusion hypothesis proposed by Modigliani and Cohn (1979) states that stock market investors fail to understand the effect of inflation on nominal dividend growth rates and extrapolate historical growth rates even in periods of changing inflation. From a rational investor's perspective, this implies that stock prices are undervalued when inflation is high and overvalued when inflation is low. Campbell and Vuolteenaho (2004) find that the regression coefficient of the mispricing component on inflation is positively and statistically significant, and their results provide strong support to the inflation illusion hypothesis. Fama (1981) considers the negative correlation between stock returns and inflation as the consequence of proxy effects. He explains in his proxy hypothesis that there is no causal relationship between the two variables. Instead, both variables are driven by real economic activity. Stock returns are determined by forecasts of relevant real variables, and negative stock return-inflation relations are induced by negative relations between real activity and inflation. The negative stock return-inflation relations are induced by negative relations between inflation and real activity which in turn are explained by a combination of money demand theory and the quantity theory of money.

Feldstein (1980) argues that an important adverse effect of increased inflation on 
share prices results from basic features of the current U.S. tax laws, particularly historic cost depreciation and the taxation on nominal capital gains. When prices rise, the historic cost method of depreciation causes the real value of depreciation to fall and real taxable profits to be increased. As a result, real profits net of the corporate income tax vary inversely with inflation. Inflation further reduces net earnings by imposing an additional tax on nominal capital gains. Therefore, inflation raises the effective tax rate on corporate income and lowers the share price. In a recent attempt, Brandt and Wang (2003) put forward a time-varying risk aversion hypothesis. They formulate a consumption-based asset pricing model in which aggregate risk aversion is time-varying in response to news about consumption growth and inflation. They document a robust correlation between aggregate risk aversion and unexpected inflation. Katz et al. (2017) investigate why local stock markets adjust slowly to changes in local inflation. They find that when the local rate of inflation increases, local investors subsequently earn lower real returns on local stocks, suggesting that the local stock market investors use sticky long-run nominal discount rates that are too low when inflation increases because they are slow to update the inflation expectations in discount rates. They show that small amounts of stickiness in inflation expectations are sufficient to match the real stock return predictability induced by inflation in the data.

There is another strand of the literature that emphasizes the role of monetary policy in determining stock returns and inflation. The rationale is that central banks that are targeting inflation will respond to inflation shocks. As a result, the changing stance of monetary policy prompts stock market revaluations. Sellin (2001) gives a comprehensive review of the literature on the interaction between stock returns, inflation, and money growth, with a special emphasis on the role of monetary policy. Kaul (1987) hypothesizes that the relation between stock returns and inflation is caused by equilibrium processes in the monetary sector. He shows that the negative stock return-inflation relations are caused by money demand and countercyclical money supply effects. Geske and Roll (1983) argue that this puzzling empirical phenomenon is due to the fiscal and monetary linkage. Exogenous shocks in real output, signaled by the stock market, induce changes in tax revenue, then the Treasury borrows more and the central bank monetizes the increased debt. Rational investors adjust prices accordingly without a delay. Using Markov regime-switching models, Chen (2007) points out that monetary policy has asymmetric effects on stock returns. 
In a thought-provoking paper, Bakshi and Chen (1996) show that there exists a negative correlation between real equity return and inflation within a general equilibrium, unless both money growth is procyclical and its covariance with output growth dominates the variance of output growth. In a Cash-in-Advance model, Boyle and Peterson (1995) show that equity returns are negatively correlated with inflation when monetary policy is countercyclical or weakly procyclical. In another equilibrium monetary asset pricing model, Marshall (1992) predicts that the inflation-asset return correlation will be more strongly negative when inflation is generated by fluctuations in real economic activity than when it is generated by monetary fluctuations. In an influential paper, Christiano et al. (2010) show that historically, inflation is low during stock market booms in the United States and Japan. The authors use the concept of a news shock, i.e., a disturbance to information about next period's innovation in technology, to interpret the evidence. They argue that an interest rate rule that is too narrowly focused on inflation destabilizes asset markets and the broader economy.

The paper revisits the existing monetary economics hypotheses in the stock returninflation literature and contribute to the literature by highlighting the role of monetary policy. It intends to confirm monetary policy as a determining factor in the stock return-inflation relationship based on empirical findings under different monetary policy regimes and conditions. It empirically confirms that central banks can shape the way stock markets react to inflation from three different angles: monetary policy cyclicality, monetary policy framework, and whether monetary policy is constrained by the Zero Lower Bound. In addition, this paper contributes to the inflation targeting literature by revealing that inflation targeting countries are different. Based on a stark comparison of central banks' track record of controlling inflation, results show that inflation targeting countries are heterogeneous and stock markets differentiate inflation targeting countries by their behaviors.

\section{Data Description and Stylized Facts}

I compile a quarterly dataset using readily available data from the first quarter of 1980 to the second quarter of 2015. The sample includes 71 economies, including 33 advanced markets and 38 emerging markets. It integrates data from the International Monetary Fund (IMF), Bloomberg, Haver Analytics, Thomson Reuters Datastream, 
Consensus Forecasts, and other sources. The dataset is an unbalanced panel, that is, countries do not have the same number of observations in the study. For example, the stock market has a long history in advanced markets, while for emerging markets it is a recent phenomenon. The issue of data availability is also true for other variables.

The variable construction and data source of key variables are as follows (see details in appendix). Equity index data is from Bloomberg, and nominal stock return is the change in equity index logarithm from one year ago. Consumer price index data is from the IMF's INS database, and inflation is defined as the change in the Consumer Price Index (CPI) logarithm from one year ago. Real equity index is derived by deflating nominal equity index by consumer price index accordingly, and real stock return is the change in real equity price logarithm from one year ago. Inflation forecasts are current-year and next-year market forecasts from Consensus Forecasts. Industrial production data is obtained from combining Thomson Reuters Datastream and the IMF's data. M2, a measure of aggregate money supply, comes from Haver Analytics and the IMF. Financial sector risk ratings are provided by the International Country Risk Guide (ICRG). The United States three-month Treasury bill yield rate in secondary markets is downloaded from the Board of Governors of the Federal Reserve System. Finally, the VIX index is retrieved from Bloomberg.

Table 1 summarizes the basic statistics for key indicators used in this paper. ${ }^{1}$ Nominal stock returns on average are 0.11 , and the standard deviation is 0.40 with a minimum of -2.47 and a maximum of 5.23. Since the nominal stock return is the change in logarithm, the mean value represents an $11 \%$ increase on an annual basis, the minimum value represents a $92 \%$ drop on an annual basis (Iceland in 2009) and the maximum value represents an 18,535\% increase on an annual basis (Argentina in 1989)! The shocking numbers represent several formidable stock market crashes and hyperinflation episodes in emerging market economies. Real stock returns on average are 0.04 , with minimum -2.63 and maximum 2.23. This means real stock return on average is about $4 \%$ annually. When adjusted for inflation, the large stock market gains at the positive tail of the distribution are smaller in real terms but still very sizable. Inflation is as volatile as stock returns, and its mean is 0.11. The minimum value -0.41 and the maximum value 4.95 suggest there are serious deflation and hyperinflation episodes. Industrial production is an index that measures the real

\footnotetext{
${ }^{1}$ Several key variables are transformed into log forms to avoid extreme values. Hyperinflation periods are dropped for robustness check on the regression, and the result is included in the appendix.
} 
Table 1: Summary Statistics

\begin{tabular}{cccccc}
\hline Variable & Observation & Mean & Std. dev. & Min & Max \\
\hline Nominal stock return $(\log )$ & 6,304 & 0.105 & 0.399 & -2.469 & 5.227 \\
Real stock return $(\log )$ & 6,304 & 0.038 & 0.347 & -2.627 & 2.231 \\
Inflation $(\log )$ & 8,855 & 0.114 & 0.333 & -0.414 & 4.950 \\
Industrial production growth $(\log )$ & 6,443 & 0.028 & 0.079 & -0.675 & 0.730 \\
Monetary aggregate growth $(\log )$ & 6,399 & 0.147 & 0.237 & -0.378 & 4.138 \\
Improvement in financial risk rating & 7,960 & 0.022 & 1.536 & -17 & 17 \\
U.S. Treasury bill rate & 10,082 & 4.594 & 3.589 & 0.01 & 15.49 \\
VIX & 7,242 & 19.89 & 7.45 & 11.26 & 44.14 \\
\hline
\end{tabular}

output of certain industrials, and it has smaller fluctuations compared to the abovementioned financial and nominal variables. Industrial production on average grows $2.9 \%$ per annum for the selected sample countries. On the other hand, M2 growth rate exhibits a rather heterogeneous distribution. It has a mean of 0.15 with its lowest value being -0.38 and the highest value being 4.14 . The ICRG's financial sector risk ratings are ranging from 0 to 50 , where 50 indicates the least risk and 0 indicates the highest risk. The change in financial risk is the quarter-over-quarter difference in financial sector risk ratings, and a positive change indicates a reduction in financial sector risk. On average the variable is quite stable, but the top and bottom values certainly show that there are periods associated with large upgrades or downgrades of financial risk. Lastly, the VIX index, which is a volatility index calculated by the Chicago Board Options Exchange (CBOE) is a key measure of market expectations of near-term volatility conveyed by the S\&P 500 stock index option prices. It has been considered by many to be the world's premier barometer of investor sentiment and market volatility. Its average is 19.9 and volatility is low during most of the times. However, during times of market stress such as the Global Financial Crisis and the European sovereign debt crisis, the index rises above a high level of 40 .

Figure 2 plots the key series together. Over the long run, nominal equity indices and consumer price indices mimic each other. In advanced markets such as the United States, the stock index tracks the consumer price index quite closely in the long term. Typically for an advanced market, the consumer price index is very stable and the equity index is volatile. This is because inflation is well-anchored in advanced markets, as a result, real stock returns track closely with the nominal stock returns. In 


\section{Advanced Markets}
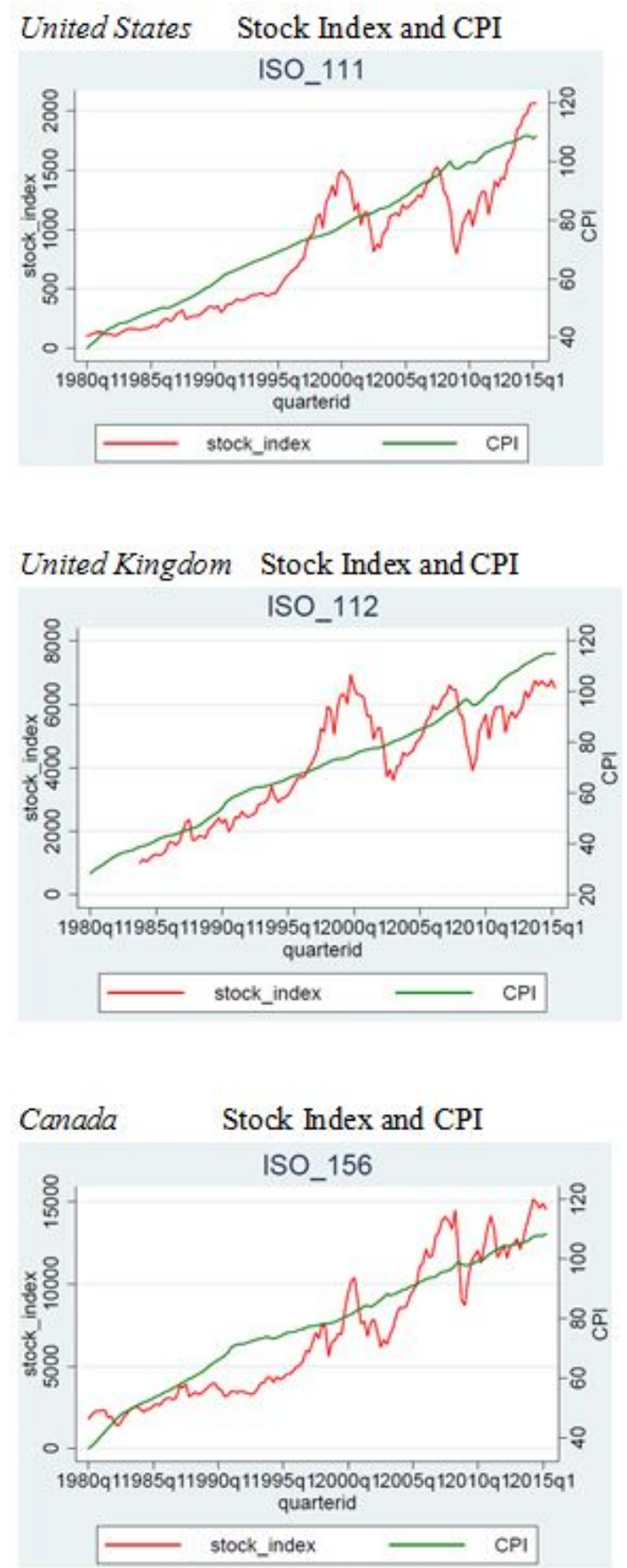

Inflation, nominal and real stock retums

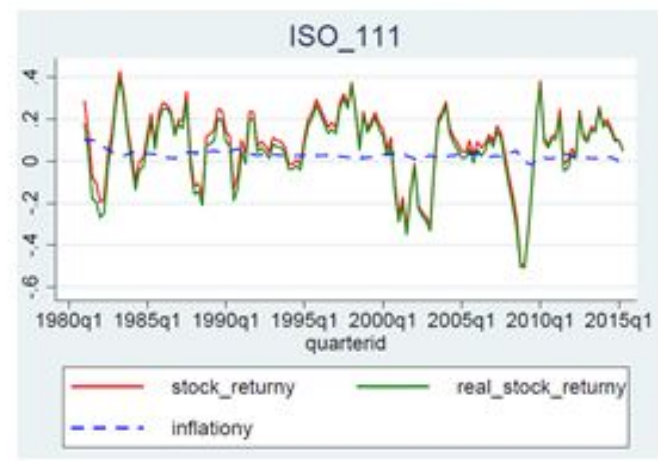

Inflation, nominal and real stock retums

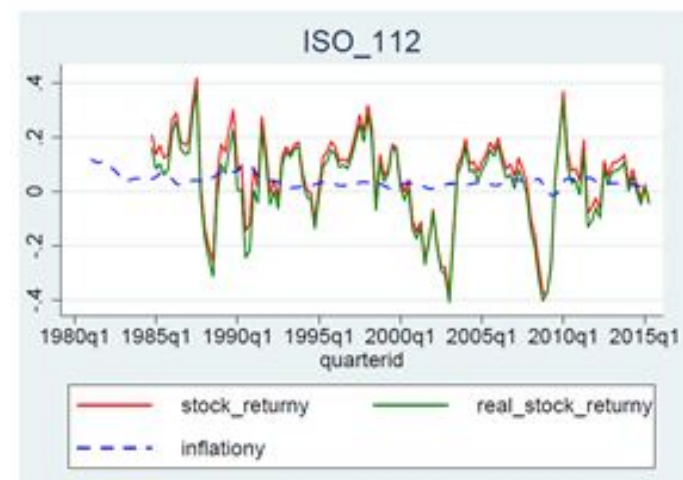

Inflation, nominal and real stock returns

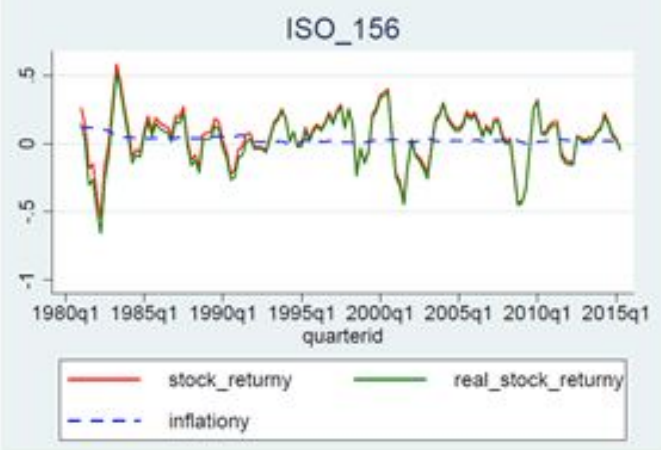




\section{Emerging Markets}

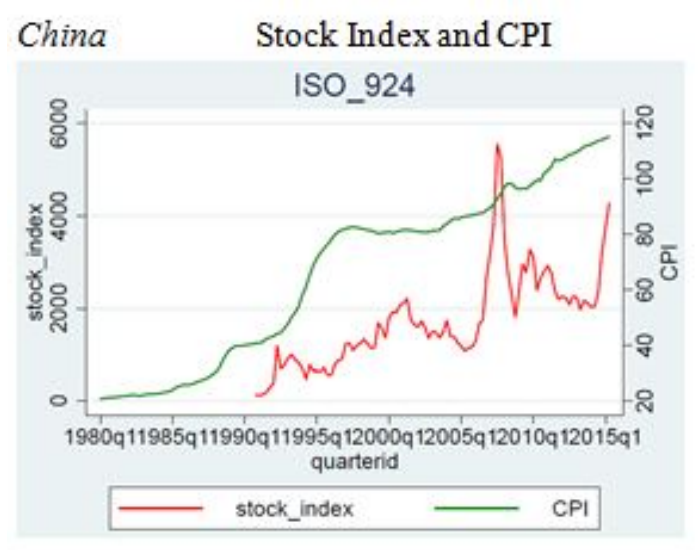

Inflation, nominal and real stock retums
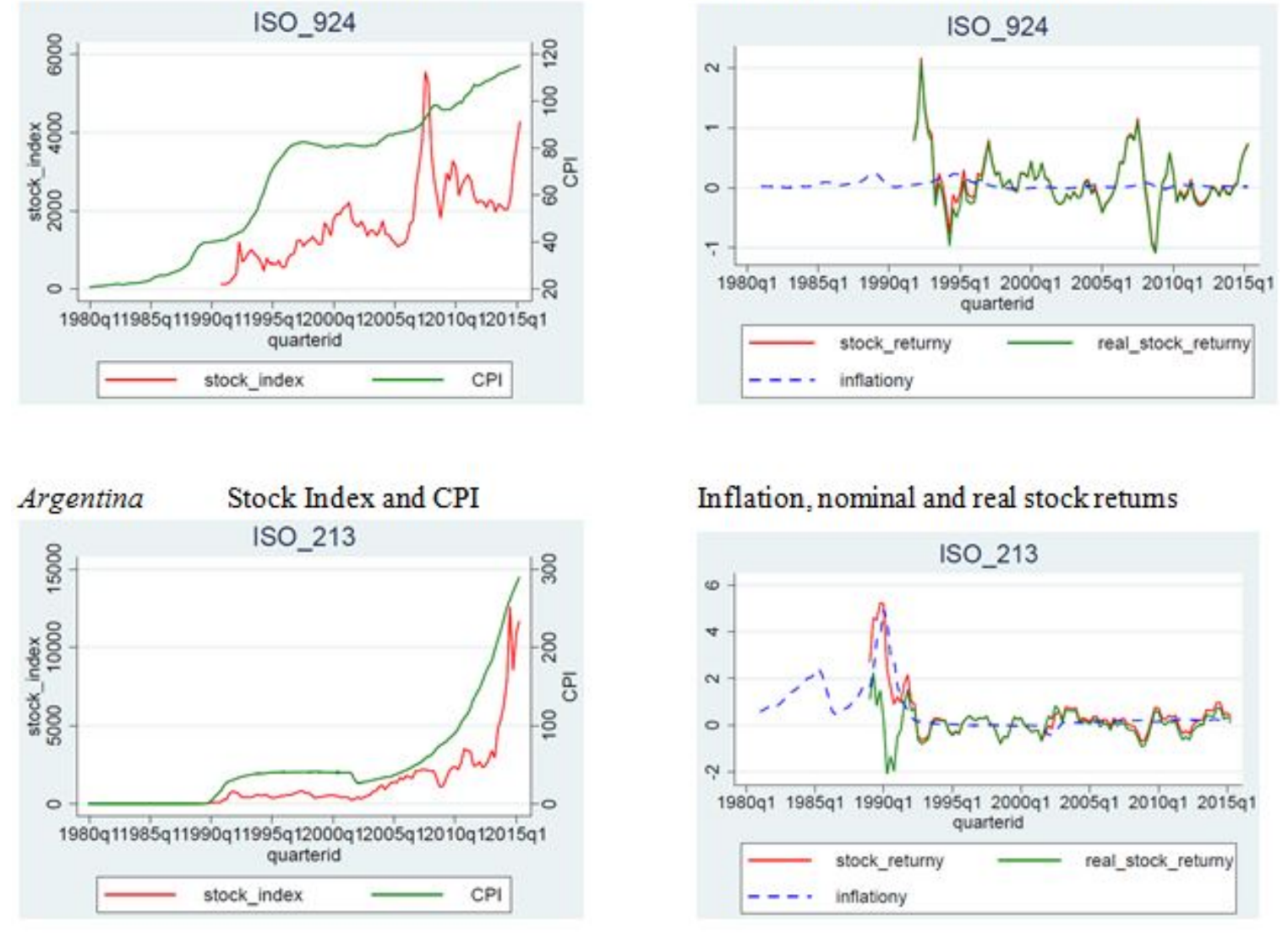

Inflation, nominal and real stock retums
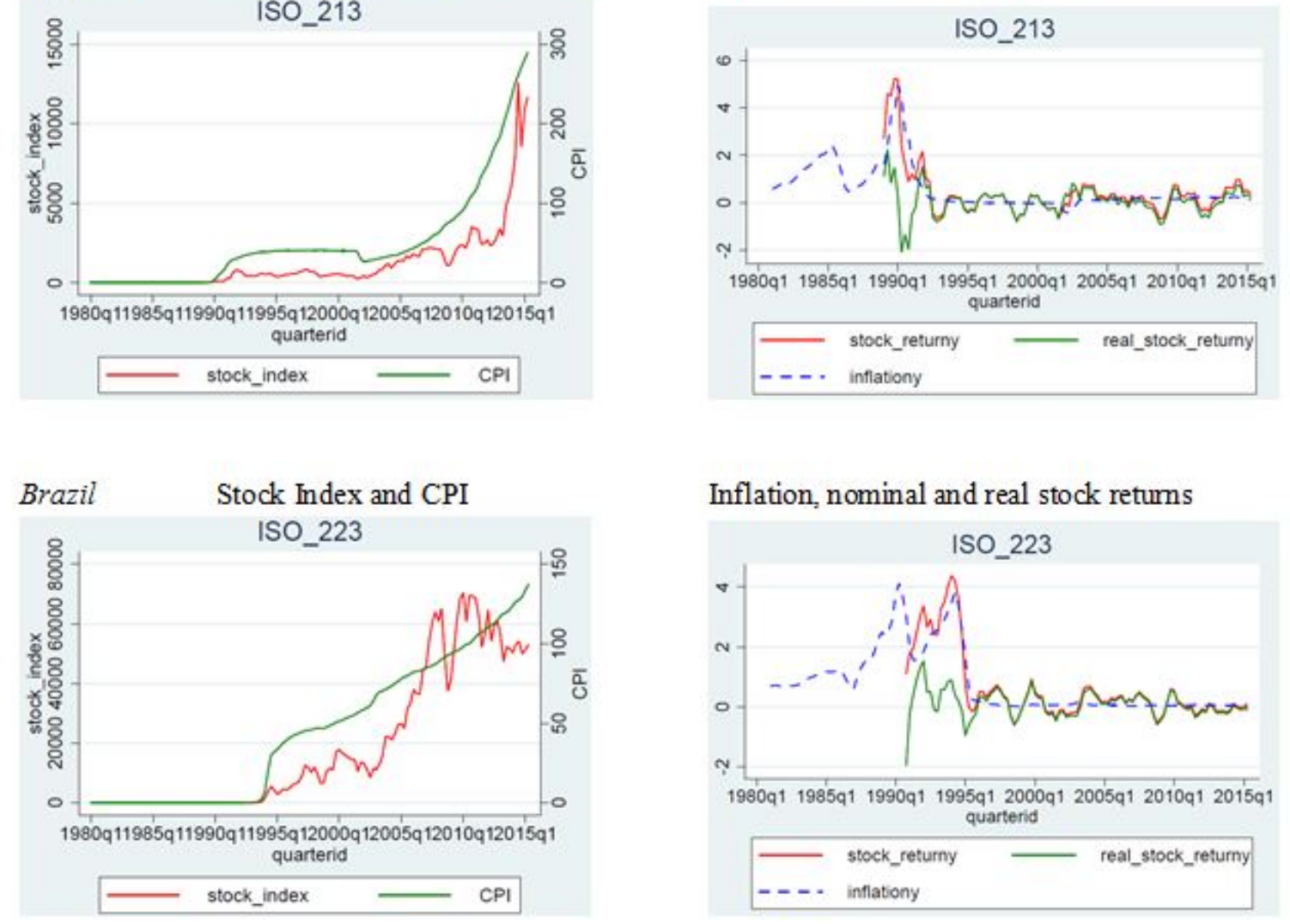

Inflation, nominal and real stock returns

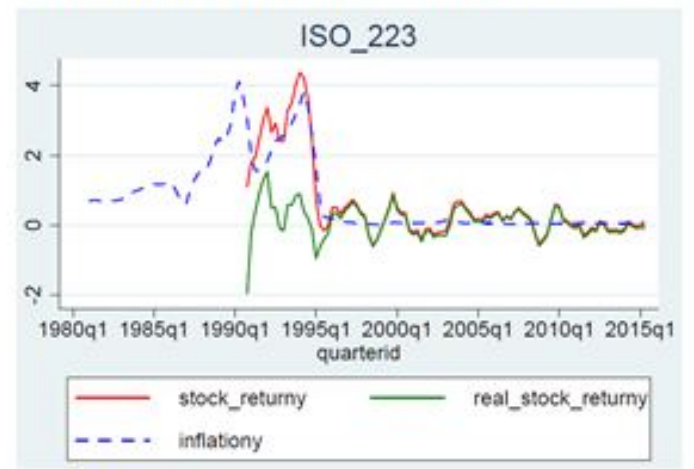


emerging markets, there exists a larger degree of heterogeneity. Usually stock markets have experienced large swings of price movements, as well as boom and bust episodes. The heterogeneity is partly due to differentiated inflation dynamics across emerging markets. Central banks face big challenges to tame inflation and maintain macroeconomic stability. Several countries, including Argentina and Brazil, have experienced hyperinflation in the past decades. Nominal equity indices rise passively in response to high inflation. Real stock returns, on the other hand, have diverged from nominal stock returns under such circumstances. The divergence between nominal and real stock returns is only observed during high inflation periods.

To prepare for regression analysis, the literature typically breaks down inflation into two terms: expected and unexpected inflation. Two classes of expected inflation are considered in this study: survey measures of expected inflation from Consensus Forecasts, and derived expected inflation from time series models. I use predicted values of inflation based on the $\mathrm{AR}(4)$ model as the default measure of expected inflation. The unexpected inflation is actual inflation minus expected inflation. In the robustness check, survey measures of expected inflation from Consensus Forecasts are used to examine whether the main results are sensitive to the measure of expected inflation. ${ }^{2}$

\section{Empirical Results}

Figure 3 shows that over time, the evolution of inflation was very different in emerging markets compared to advanced markets. The early 1970s have witnessed the collapse of the Bretton Woods System. It was followed by a time of turmoil, amid large exchange rate fluctuations and high inflation pressures. For advanced countries, the 1980s was a decade of high inflation. Starting in the mid-1980s, inflation was tamed in advanced countries: the Great Moderation period started and since then inflation was low and macroeconomic volatility was small. Emerging markets' inflation development was more volatile. The 1985-1995 period marked a decade of high inflation, with crises in Latin America and difficulties faced by the transition

\footnotetext{
${ }^{2}$ It is useful to consider alternative measures of inflation such as core inflation. However, not all countries publish core inflation data and it is more difficult to quantify expected core inflation as survey forecasts of core inflation are less prevalent.
} 
economies. Since 2000, emerging markets embraced a golden period for growth, their inflation was largely controlled ever since. However, emerging markets in general have always experienced higher inflation levels than advanced markets. Stopping high inflation was particularly challenging for them during the 1980s and 1990s. Reining in inflation becomes a key objective for the central banks, and central banks are searching for a new nominal anchor. A number of countries have adopted inflation targeting as their new monetary policy regime.

Figure 4 plots the correlations between real stock returns and inflation across countries. Given the x-axis is in logarithm, inflation is strikingly high in a number of emerging countries. When inflation is low, advanced markets and a few emerging markets tend to have negative or close-to-zero correlations between real stock returns and inflation. As inflation increases, the correlation becomes more dispersed among a group of emerging markets. In extreme cases of hyperinflation, Argentina and Brazil's correlations are close to zero. This is because under this case, real stock returns are trivial compared to inflation. Therefore, nominal stock returns are dominated by inflation and the Fisher equation holds almost perfectly. More notably, there seems to exist an upper bound for the correlation, where countries are capped at 0.2. Without any frictions, the correlation between real stock returns and inflation should be zero. Previously, the literature has focused mostly on the low inflation cases or a few hyperinflation countries. This figure gives a more comprehensive view. It also highlights the differences between advanced and emerging markets, and the heterogeneity within emerging markets.

\subsection{Initial Empirical Results on Real Stock Returns}

Since real stock returns truly matter to investors, I examine the relationship between real stock returns and inflation. The real stock index is derived from deflating the nominal stock index by the consumer price index, and the real stock return is the year-on-year difference of real stock index in natural logarithm. ${ }^{3}$ The baseline regression applies panel regressions with fixed effects to evaluate the effect of inflation on real stock returns:

\footnotetext{
${ }^{3}$ Country-level stock market indices may not capture the sectoral idiosyncrasies in the stock market. Using granular firm-level data could overcome this limitation. I leave this issue to future research.
} 
Figure 3: Evolution of Average Inflation in Logarithm by Income Group

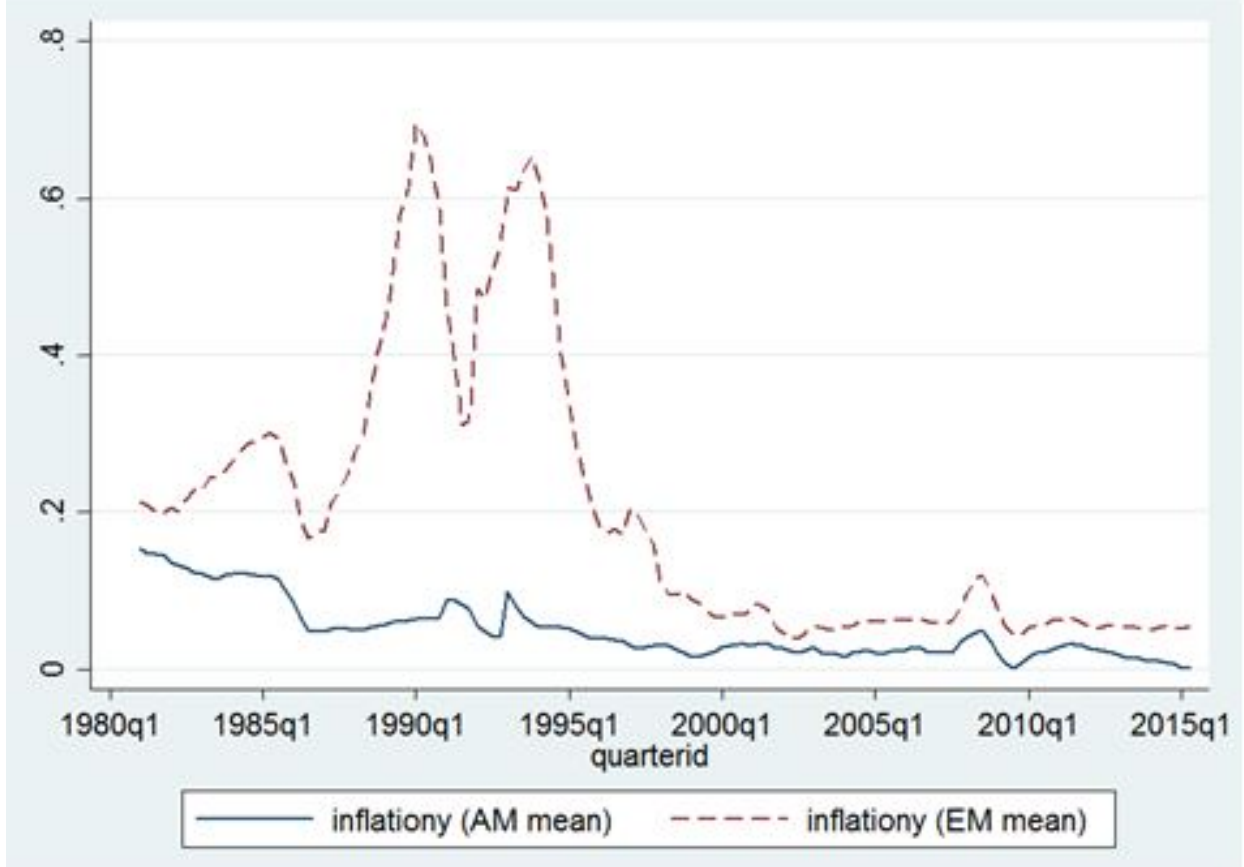

Figure 4: Scatter Plots of Average Inflation in Logarithm (x-axis) and the Unconditional Correlation between Real Stock Return and Inflation (y-axis)

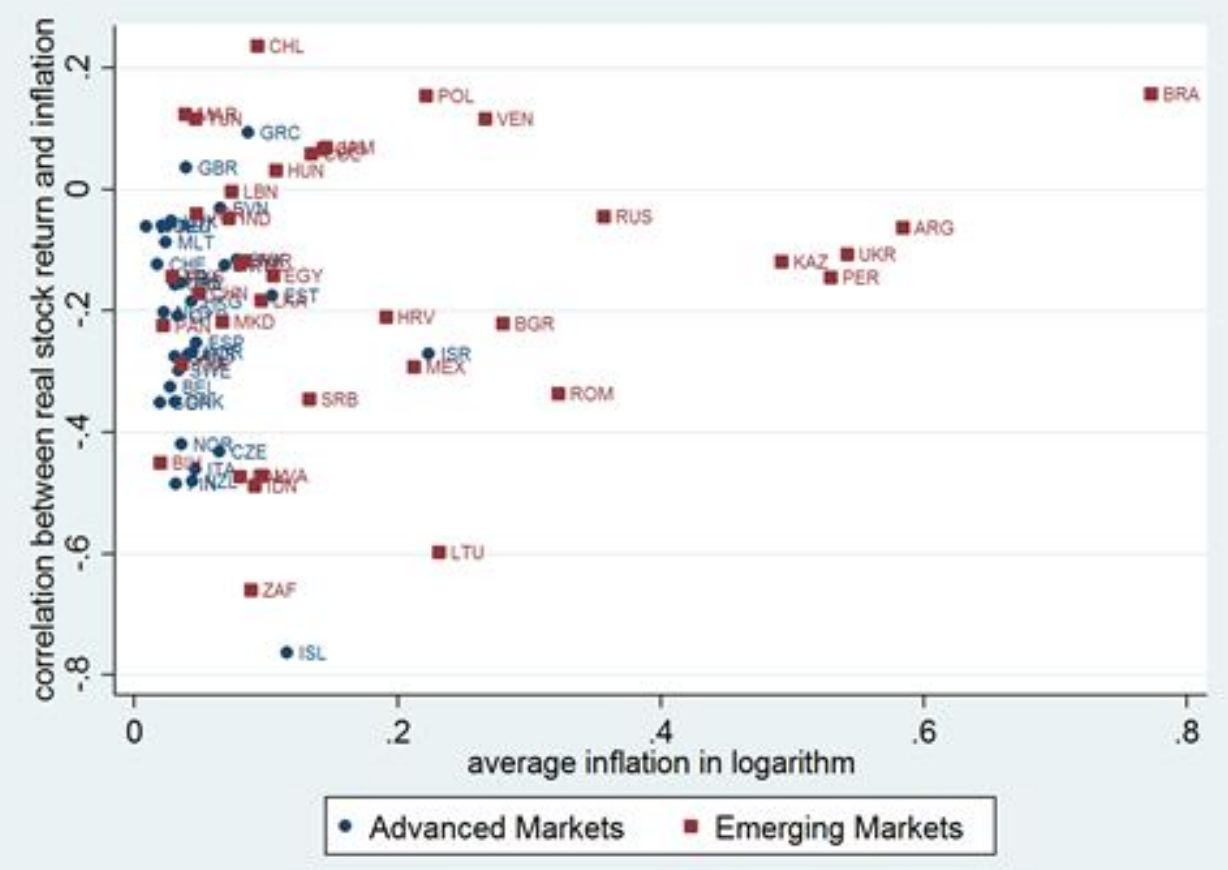




$$
Y_{i, t}=\beta_{0}+\beta_{1} \pi_{i, t}^{e}+\beta_{2} \pi_{i, t}^{u}+X B+u_{i}+\epsilon_{i, t},
$$

where $Y_{i, t}$ is real return on equity index for country $\mathrm{i}$ at time $\mathrm{t}, \pi^{e}$ and $\pi^{u}$ are expected and unexpected inflation ${ }^{4}$, and $\mathrm{X}$ is a vector of standard control variables in the literature (Fama, 1981; Chen, Roll, and Ross 1986; Schmeling, 2009; Schmeling and Schrimpf, 2011), including industrial production growth rate, change in financial risk, the U.S. three-month Treasury bill yield and the VIX. The first two control variables are country-specific factors: the industrial production growth rate accounts for the changes in the real economic activity; and change in financial risk considers the movements of the financial sector factors. The last two control variables capture the external conditions, where the U.S. three-month Treasury bill yield represents the level of the global liquidity condition, and the VIX is a measure of global financial market volatility. By examining the estimated coefficients $\beta_{1}$ and $\beta_{2}$ from the regression, one can investigate whether there exists a positive or negative correlation between stock market return and inflation across countries.

Table 2 shows the results from baseline regression without monetary policy factors. ${ }^{5}$ Results from a panel regression model with fixed effects suggest that real stock returns are positively correlated to expected inflation, industrial production growth, improvement in financial risk ratings, and negatively correlated to the VIX index. When the sample is split by income group, the asymmetric responses of real stock returns to inflation are highlighted: in advanced markets the relation is negative whereas in emerging markets it is positive. In advanced markets, real stock returns respond very negatively to expected inflation. Changes in financial risk ratings are no longer determining real stock returns, but in emerging markets they are still the determinants. The U.S. three-month Treasury bill yield appears to be positively correlated with real stock returns in advanced markets, however, the correlation is

\footnotetext{
${ }^{4}$ The literature hypothesizes that stock returns react differently to expected and unexpected inflation. For example, Brandt and Wang (2003) concentrate on unexpected inflation and aggregate risk aversion to explain stock returns. I just follow the literature to break down inflation into two components. However, the readers do not need to focus too much on the decomposition of inflation. In the first robustness check, I report the core regression results using the actual inflation.

${ }^{5}$ Before the regressions, unit root tests are performed using Augmented Dickey-Fuller, DF-GLS and Phillips-Perron tests on each variable by country, as well as Im-Pesaran-Shin and Fisher-type tests. Given the panel data is unbalanced in nature, several panel unit root tests are not applicable. Detailed results are available upon request.
} 
insignificant in emerging markets.

Results from the above panel regressions with fixed effects provide a general idea of how real stock returns react to inflation and other control variables. However, given the nature of the panel data, the results may be biased due to several econometric issues. The first issue with the panel regressions is serial correlation, because the dependent variable stock return is a financial variable that is typically exposed to such a problem. The Wooldridge Test for autocorrelation in panel data suggests that the null hypothesis that there is no first-order autocorrelation is rejected at the $1 \%$ significance level. The second weakness that the panel regressions may suffer from is heteroscedasticity. This is because countries at different stages of stock market development can have distinct variability of the error terms. The modified Wald Test for groupwise heteroscedasticity has confirmed the conjecture, and the null hypothesis that all the variances are identical across the units is rejected at the $1 \%$ significance level. A third potential source of estimation bias is from cross-sectional dependence. Intuitively, stock returns in major financial markets can cause significant spillover effects upon other markets. Unfortunately, the popular tests for cross-sectional dependence including the Breusch-Pagan LM Test are not applicable given the panel data employed here are highly unbalanced. Standard panel data techniques that fail to account for cross-sectional or spatial dependence will result in inconsistently estimated standard errors. To address serial correlation, heteroskedasticity, and the potential bias from cross-sectional dependence, I apply the Driscoll-Kraay standard error estimators to the same panel regression. Driscoll and Kraay (1998) estimate standard errors by employing a nonparametric estimation procedure to obtain consistent covariance matrix estimation with spatially dependent panel data when the time dimension is large. ${ }^{6}$ Given the quarterly panel dataset is long in the time dimension, the Driscoll-Kraay estimator is appropriately here. ${ }^{7}$

The last three columns of Table 2 present the results of panel regressions using the Driscoll-Kraay standard error estimator. The findings are largely consistent with previous ones and the standard errors do not change dramatically. For the full sam-

\footnotetext{
${ }^{6}$ For a recent implementation and discussion, see Hoechle (2007).

${ }^{7}$ Cluster standard error estimator assumes independence across clusters but correlation within clusters. It does not account for cross-sectional dependence. Since stock market returns are often spatially dependent, e.g., U.S. stock market returns affect stock market performance in other countries, the Driscoll-Kraay standard error estimator is the best approach given the nature of the dataset. Running regressions using clustered standard errors yield similar results.
} 
Table 2: Regressions without Monetary Policy Factors

\begin{tabular}{ccccccc}
\hline Dependent variable: real stock return & $(1)$ & $(2)$ & $(3)$ & $(4)$ & $(5)$ & $(6)$ \\
\hline Expected inflation & -0.141 & $-6.236^{* * *}$ & -0.111 & -0.141 & $-6.236^{* * *}$ & -0.111 \\
& $(0.111)$ & $(1.180)$ & $(0.103)$ & $(0.0984)$ & $(1.155)$ & $(0.0957)$ \\
Unexpected inflation & $0.450^{* *}$ & -1.323 & $0.522^{* * *}$ & $0.450^{*}$ & -1.323 & $0.522^{* *}$ \\
& $(0.193)$ & $(1.249)$ & $(0.161)$ & $(0.263)$ & $(1.249)$ & $(0.257)$ \\
Industrial production growth rate & $1.288^{* * *}$ & $0.993^{* * *}$ & $1.533^{* * *}$ & $1.288^{* * *}$ & $0.993^{* * *}$ & $1.533^{* * *}$ \\
& $(0.162)$ & $(0.197)$ & $(0.196)$ & $(0.158)$ & $(0.183)$ & $(0.180)$ \\
Improvement in financial risk rating & $0.00973^{* * *}$ & 0.00135 & $0.0198^{* * *}$ & 0.00973 & 0.00135 & $0.0198^{* * *}$ \\
& $(0.00327)$ & $(0.00371)$ & $(0.00443)$ & $(0.00597)$ & $(0.00624)$ & $(0.00596)$ \\
U.S. 3-month Treasury bill yield rate & 0.00209 & $0.0219^{* * *}$ & -0.00551 & 0.00209 & $0.0219^{* *}$ & -0.00551 \\
& $(0.00413)$ & $(0.00616)$ & $(0.00649)$ & $(0.0107)$ & $(0.00925)$ & $(0.0138)$ \\
vix & $-0.0168^{* * *}$ & $-0.0149^{* * *}$ & $-0.0164^{* * *}$ & $-0.0168^{* * *}$ & $-0.0149^{* * *}$ & $-0.0164^{* * *}$ \\
& $(0.00100)$ & $(0.000835)$ & $(0.00146)$ & $(0.00340)$ & $(0.00245)$ & $(0.00392)$ \\
Constant & $0.340^{* * *}$ & $0.395^{* * *}$ & $0.346^{* * *}$ & $0.340^{* * *}$ & $0.395^{* * *}$ & $0.346^{* * *}$ \\
& $(0.0214)$ & $(0.0323)$ & $(0.0344)$ & $(0.0750)$ & $(0.0637)$ & $(0.0856)$
\end{tabular}

$\begin{array}{ccccccc}\text { Estimation method } & \text { FE } & \text { FE } & \text { FE } & \text { DK } & \text { DK } & \text { DK } \\ \text { Sample } & \text { full } & \text { AM } & \text { EM } & \text { full } & \text { AM } & \text { EM } \\ \text { Observations } & 4,573 & 2,557 & 2,016 & 4,573 & 2,557 & 2,016 \\ \text { R-squared } & 0.288 & 0.405 & 0.288 & 0.288 & 0.405 & 0.289 \\ \text { Number of countries } & 63 & 31 & 32 & 63 & 31 & 32\end{array}$

Note: Robust standard errors in parentheses. ${ }^{* * *} \mathrm{p}<0.01{ }^{* *} \mathrm{p}<0.05 ;^{*} \mathrm{p}<0.1$. FE $=$ Panel Regressions with Fixed Effects; DK = Panel Regressions with Fixed Effects and Driscoll-Kraay standard errors; AM = Advanced Markets; EM

= Emerging Markets. Hausman test suggests using fixed effects model, instead of random effects model. 
ple, on average one percentage point increase in the growth rate of expected inflation is correlated with a 0.14 percentage point decrease in the growth rate of real stock returns, and one percentage point increase in the growth rate of unexpected inflation is correlated with a 0.45 percentage point increase in the growth rate of real stock returns. One percentage point increase in the growth rate of industrial production is associated with a 1.29 percentage point increase in the growth rate of real stock returns. Neither improvement in financial risk rating nor the U.S. three-month Treasury bill yield rate matters given the estimated coefficients are not significant. Lastly, one unit increase in the market volatility, as indicated by the VIX index, lowers the growth rate of real stock returns by 1.7 percentage points. ${ }^{8}$

Markets react more acutely to inflation in advanced countries. In advanced markets, real stock returns react negatively to expected inflation. A one percentage point increase in the growth rate of expected inflation lowers the growth rate of real stock returns by 6.24 percentage points. In emerging markets, unexpected inflation is positively associated with real stock returns. One percentage point increase in the growth rate of unexpected inflation boosts the growth rate of real stock returns by 0.52 percentage points. One reason to explain how markets respond to inflation is because inflation is controlled within a much smaller range in advanced markets than that of the emerging markets. Therefore, markets are less sensitive to one unit of inflation shock in emerging markets. Comparing the two classes of countries, improvements in financial risk ratings positively drive real stock returns in emerging markets, but not significant in advanced markets; the U.S. Treasury bill yield positively raise real stock returns in advanced markets, but not significant in emerging markets. The differences may be linked to the extent of vulnerabilities in the financial sectors, since emerging markets are perceived to be exposed to greater financial risk. The differences may also come from the level of financial development, since stock markets in advanced countries are more mature. Investors are more rational and have better access to information.

\footnotetext{
${ }^{8}$ Since the functional form is log-level, i.e., the dependent variable is in logs and the independent variable is in levels, we need to multiply the estimated coefficient on the VIX index by $100 \%$ to interpret the economic meaning. The same logic holds for the change in financial risk rating and the Treasury bill yield rate.
} 


\subsection{Augmented Regressions on Stock Returns with Mone- tary Policy Considerations}

While many economists argue for nonmonetary factors contributing to the negative stock return-inflation correlation, there is another strand of the literature which attributes to monetary policy the role of shaping the stock return-inflation relations. Monetary economists argue that the observed relationship between stock returns and inflation is largely spurious. Instead, the relationship is driven by monetary policy, since central banks around the world aim at controlling inflation and their actions towards fighting inflation often have unintended consequences on stock prices. When inflation rises, a central bank who is "leaning against the wind" hikes its policy rate to combat inflation. This is bad news for stock markets since increases in policy rates will tighten market liquidity and put downward pressure on stock returns. However, if monetary policy is acyclical, the monetary authority does nothing against inflation movements thus stock markets are not affected. If monetary policy is procyclical, then the monetary authority instead lowers the policy rate when inflation increases, which boosts stock market performance.

As noted by researchers such as Kaminsky, Reinhart and Vegh (2005), monetary policy is usually countercyclical in advanced markets and procyclical in emerging markets. Therefore, an interesting question is whether the relations between real stock returns and inflation in developed and developing countries can be explained by how their central banks pursue monetary policies. Previously, due to data limitations, researchers are constrained by testing the existing hypotheses in the literature in a cross-country setting. This newly compiled dataset made testing the existing hypotheses from an international perspective possible. Specifically, I test the role of monetary policy from three aspects. First, I allow various degrees of policy rate cyclicality across countries to investigate whether monetary policy cyclicality matters. Second, I examine different monetary policy frameworks, i.e., inflation targeting versus exchange rate anchor. Third, I study the Zero Lower Bound episodes when monetary policy is constrained.

In the spirit of the monetary policy hypothesis in the literature, I augment the panel regressions by introducing monetary factors and making two changes to the previous regressions. Monetary aggregate (M2) growth rate is included as an extra 
control variable and then interaction terms between monetary policy cyclicality and inflation are added to the regressions. The augmented regression with country fixed effects has the following setup:

$$
Y_{i, t}=\beta_{0}+\beta_{1} \pi_{i, t}^{e}+\beta_{2} \pi_{i, t}^{u}+\beta_{3} \pi_{i, t}^{e} C_{i}+\beta_{4} \pi_{i, t}^{u} C_{i}+Z \Gamma+u_{i}+\epsilon_{i, t}
$$

where $C_{i}$ is a measure of monetary policy cyclicality for country $\mathrm{i}$, and $\mathrm{Z}$ is a vector of control variables including monetary aggregate (M2) growth rate. The monetary aggregate growth rate variable captures the direct effect of increases in monetary aggregate on stock market returns.

Introducing the interaction terms between monetary policy cyclicality and inflation is key to disentangle how monetary policy cyclicality affects the stock returninflation relation. Without the interaction terms, the effects of expected and unexpected inflation on stock returns are $\beta_{1}$ and $\beta_{2}$. When interaction terms are added, the effects of expected and unexpected inflation on stock returns are now $\beta_{1}+\beta_{3} * C_{i}$ and $\beta_{2}+\beta_{4} * C_{i}$. If $\beta_{3}$ and $\beta_{4}$ statistically significant, monetary policy cyclicality changes the way stock return responds to inflation. Following Vegh and Vuletin (2012), the measure of monetary policy cyclicality is computed as the correlation between the cyclical components of real output and a central bank's policy rate. The HodrickPrescott (HP) filter is applied to derive the trend and the cyclical components, and the smoothing parameter is set at 6.25 for the annual data. ${ }^{9}$ A positive correlation between the cyclical components of real output and policy rate suggests that monetary policy is countercyclical. On the other hand, a negative correlation between the cyclical components of real output and policy rate suggests that monetary policy is procyclical. ${ }^{10}$

In most countries, the correlation between the cyclical components of real output and policy rate is mostly positive, with an average of 0.26 . Among the 61 sample countries, 45 of them have positive correlations and the rest have negative correlations. Figure 5 plots the policy rate cyclicality measure for each country based on the

\footnotetext{
${ }^{9}$ Annual data is used here because output gaps in annual frequency are more reliable. The smoothing parameter 6.25 is based on the recommended value of the hprescott command in Stata. Alternatively, the parameter is set at 100 and the results are very similar.

${ }^{10}$ Alternatively, monetary cyclicality can be computed as the correlation between the cyclical components of real output and monetary aggregates (M2). The issue with this measure is that monetary aggregate is endogenous, and it is determined by both supply and demand factors.
} 
Figure 5: Policy Rate Cyclicality Measure
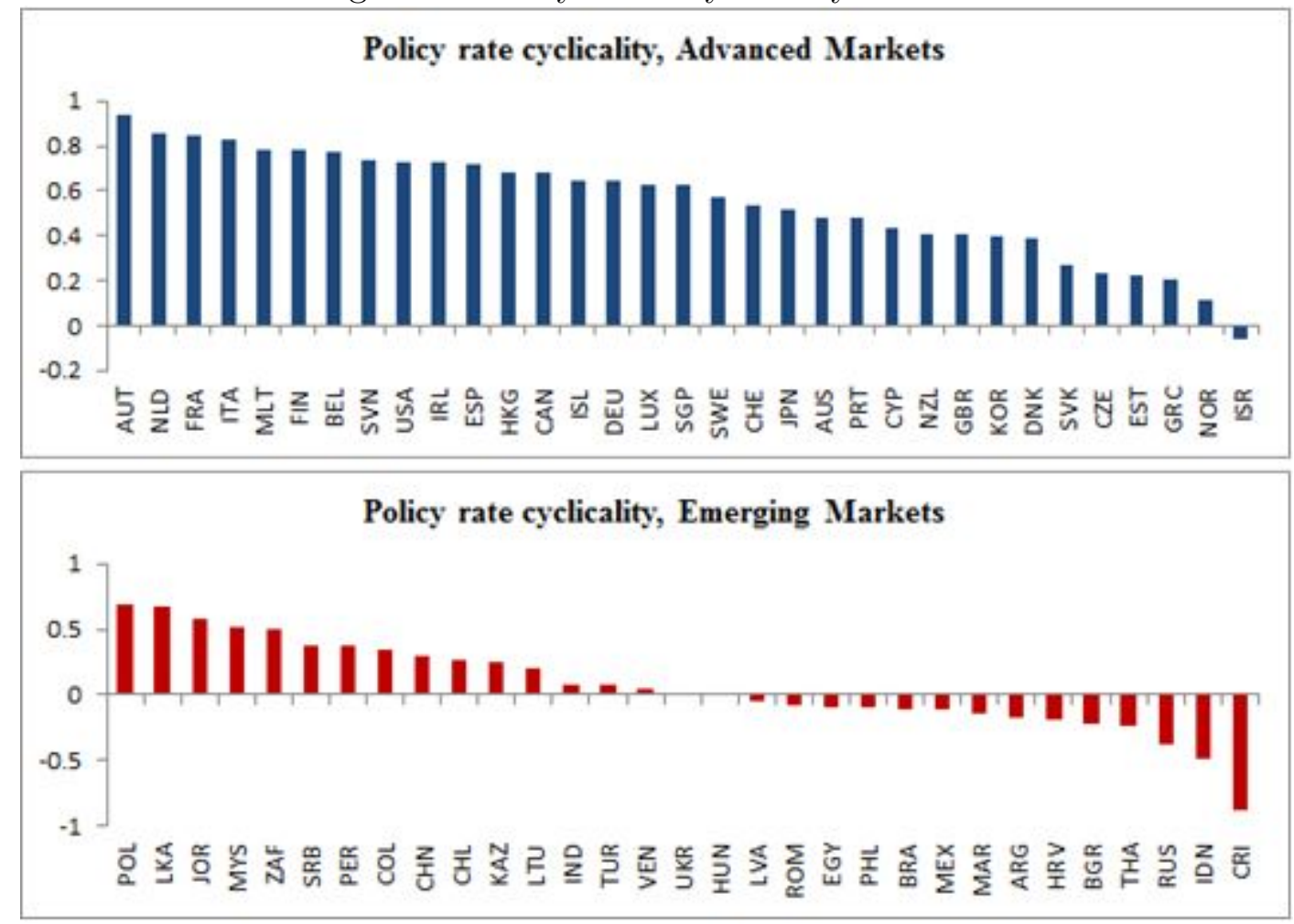

full sample period. To complement the result in regressions, I define a countercyclical policy dummy variable. This dummy variable equals one if the above correlation is greater than 0.2 and dummy variable equals zero otherwise. According to this definition, almost all advance markets pursue countercyclical monetary policies (31 out of 33, except Norway and Israel), while for emerging markets only about a third of them conduct countercyclical monetary policies (12 out of 31). Kaminsky, Reinhart and Vegh (2005) coin the phenomenon that most developing countries conduct procyclical monetary policies as "when it rains, it pours".

When monetary aggregate growth rate is included as a control variable, panel regressions show that real stock returns react negatively to inflation (Table 3). In addition, real stock returns in all the sample countries are positively correlated to industrial production growth, improvement in financial risk ratings, monetary aggregate growth and negatively correlated to expected and unexpected inflation, and the VIX index. On average a one percentage point increase in the growth rate of expected (unexpected) inflation is correlated with a $0.69(0.70)$ percentage point decrease in 
the growth rate of real stock returns. A one percentage point increase in the growth rate of industrial production is associated with a 1.19 percentage point increase in the growth rate of real stock returns. One unit of improvement in financial risk rating increases the growth rate of real stock return by 1.2 percentage points. One unit increase in the VIX index, lowers the growth rate of real stock returns by 1.7 percentage points. Finally, a one percentage point increase in the growth rate of monetary aggregate is associated with a 0.63 percentage point increase in the growth rate of real stock returns. When monetary aggregate growth is introduced as a control variable, the responsiveness of real stock returns to inflation is dampened.

When the countries are split by income levels, real stock returns respond negatively in a substantial manner to expected inflation only in advanced markets. The relationship is less negative in emerging markets. ${ }^{11}$ The financial risk rating is a determinant of real stock returns in emerging markets but not in advanced markets. The U.S. Treasury bill yield only matters for stock returns in advanced markets. The fact that monetary aggregate growth is significant in emerging markets but not in advanced markets is interesting. One conjecture to explain this phenomenon is that in recent decades advanced markets have witnessed a disconnect between monetary aggregate growth and economic fundamentals, as well as the stock market. Observing the structural break, a number of central banks have shifted their monetary policy framework from intermediate variable targeting (e.g., monetary targeting) to final variable targeting (e.g., inflation targeting). This is one of the reasons for central banks to rely more on the policy rate tool rather than the monetary aggregate tool.

Results from augmented regressions reveal an important role of monetary policy: monetary policy cyclicality alters how stock returns react to inflation. The monetary policy cyclicality measure based on the policy rate is highly negative and statistically significant, and confirms that indeed the monetary policy cyclicality changes the way real stock returns react to inflation. The estimated coefficient on the interaction term between expected inflation and monetary policy cyclicality is -5.47 , suggesting that as monetary policy becomes more countercyclical, stock returns respond more negatively to inflation. ${ }^{12}$ For instance, when monetary policy switches from acycli-

\footnotetext{
${ }^{11}$ See the result of augmented regressions using actual inflation in the robustness check section. A formal test on whether real stock returns react less negatively to inflation in emerging markets is done by adding an additional interaction term between inflation and emerging market dummy variable.

${ }^{12}$ The sample includes Eurozone countries, since the focus of the paper is not on monetary policy
} 
Table 3: Baseline Regressions on Real Stock Returns with Monetary Policy Factors

\begin{tabular}{|c|c|c|c|c|c|c|c|c|c|}
\hline Dependent variable: real stock return & $(1)$ & $(2)$ & $(3)$ & $(4)$ & $(5)$ & $(6)$ & $(7)$ & $(8)$ & $(9)$ \\
\hline Expected inflation & $\begin{array}{c}-0.686^{* * *} \\
(0.149)\end{array}$ & $\begin{array}{l}-6.407^{* * * *} \\
(1.090)\end{array}$ & $\begin{array}{c}-0.849 * * * \\
(0.173)\end{array}$ & $\begin{array}{c}-1.887^{* * *} \\
(0.338)\end{array}$ & $\begin{array}{c}-2.561^{* *} \\
(0.990)\end{array}$ & $\begin{array}{c}-1.335^{* * *} \\
(0.302)\end{array}$ & $\begin{array}{c}-0.802^{* * *} \\
(0.280)\end{array}$ & $\begin{array}{l}-2.498 \\
(1.558)\end{array}$ & $\begin{array}{c}-0.863^{* * *} \\
(0.292)\end{array}$ \\
\hline Unexpected inflation & $\begin{array}{c}-0.696^{*} \\
(0.377)\end{array}$ & $\begin{array}{l}-1.765 \\
(1.488)\end{array}$ & $\begin{array}{c}-0.878^{* * *} \\
(0.325)\end{array}$ & $\begin{array}{c}-1.288^{* *} \\
(0.535)\end{array}$ & $\begin{array}{l}-2.399 \\
(1.657)\end{array}$ & $\begin{array}{c}-1.216^{* *} \\
(0.463)\end{array}$ & $\begin{array}{l}-0.960 \\
(0.611)\end{array}$ & $\begin{array}{l}-3.096 \\
(2.127)\end{array}$ & $\begin{array}{l}-0.863^{*} \\
(0.517)\end{array}$ \\
\hline Expected inflation $\times$ policy rate cyclicality & & & & $\begin{array}{c}-5.468^{* * * *} \\
(0.916)\end{array}$ & $\begin{array}{c}-8.284^{* * *} \\
(1.704)\end{array}$ & $\begin{array}{c}-2.349^{* *} \\
(1.054)\end{array}$ & & & \\
\hline Unexpected inflation $\times$ policy rate cyclicality & & & & $\begin{array}{l}-0.595 \\
(1.316)\end{array}$ & $\begin{array}{l}2.390 \\
(2.687)\end{array}$ & $\begin{array}{l}-0.927 \\
(1.410)\end{array}$ & & & \\
\hline Expected inflation $\times$ countercyclical policy dummy & & & & & & & $\begin{array}{l}-4.445^{* * *} \\
(0.706)\end{array}$ & $\begin{array}{c}-4.387^{* *} \\
(1.768)\end{array}$ & $\begin{array}{c}-2.268^{* * *} \\
(0.734)\end{array}$ \\
\hline Unexpected inflation $\times$ countercyclical policy dummy & & & & & & & $\begin{array}{l}-1.325 \\
(0.844)\end{array}$ & $\begin{array}{l}2.615 \\
(2.063)\end{array}$ & $\begin{array}{c}-2.179^{* *} \\
(0.948)\end{array}$ \\
\hline Industrial production growth rate & $\begin{array}{c}1.187^{* * *} \\
(0.165)\end{array}$ & $\begin{array}{c}0.928^{* * *} \\
(0.193)\end{array}$ & $\begin{array}{c}1.351^{* * *} \\
(0.214)\end{array}$ & $\begin{array}{c}1.181^{* * *} \\
(0.165)\end{array}$ & $\begin{array}{c}0.872^{* * *} \\
(0.185)\end{array}$ & $\begin{array}{c}1.428^{* * *} \\
(0.229)\end{array}$ & $\begin{array}{c}1.185^{* * *} \\
(0.158)\end{array}$ & $\begin{array}{c}0.818^{* * *} \\
(0.192)\end{array}$ & $\begin{array}{c}1.445^{* * *} * \\
(0.221)\end{array}$ \\
\hline M2 growth rate & $\begin{array}{c}0.634^{* * *} \\
(0.145)\end{array}$ & $\begin{array}{l}0.0265 \\
(0.278)\end{array}$ & $\begin{array}{c}0.838^{* * *} \\
(0.160)\end{array}$ & $\begin{array}{c}0.415^{* *} \\
(0.191)\end{array}$ & $\begin{array}{l}0.0307 \\
(0.273)\end{array}$ & $\begin{array}{c}0.632^{* * *} \\
(0.174)\end{array}$ & $\begin{array}{c}0.400^{* *} \\
(0.192)\end{array}$ & $\begin{array}{l}0.0168 \\
(0.285)\end{array}$ & $\begin{array}{c}0.621^{* * *} * \\
(0.172)\end{array}$ \\
\hline Improvement in financial risk rating & $\begin{array}{c}0.0124^{* *} \\
(0.00561)\end{array}$ & $\begin{array}{c}0.00143 \\
(0.00627)\end{array}$ & $\begin{array}{c}0.0232^{* * *} \\
(0.00517)\end{array}$ & $\begin{array}{l}0.0120^{* *} \\
(0.00480)\end{array}$ & $\begin{array}{c}0.00141 \\
(0.00539)\end{array}$ & $\begin{array}{c}0.0210^{* * *} * \\
(0.00537)\end{array}$ & $\begin{array}{c}0.0119^{* *} \\
(0.00481)\end{array}$ & $\begin{array}{c}0.00161 \\
(0.00547)\end{array}$ & $\begin{array}{c}0.0209^{* * *} * \\
(0.00528)\end{array}$ \\
\hline U.S 3-month Treasury bill yield rate & $\begin{array}{c}-0.00241 \\
(0.0108)\end{array}$ & $\begin{array}{c}0.0204^{* *} \\
(0.0102)\end{array}$ & $\begin{array}{l}-0.0113 \\
(0.0134)\end{array}$ & $\begin{array}{l}0.00882 \\
(0.0101)\end{array}$ & $\begin{array}{c}0.0190^{* *} \\
(0.00953)\end{array}$ & $\begin{array}{c}-0.00186 \\
(0.0131)\end{array}$ & $\begin{array}{c}0.00967 \\
(0.00993)\end{array}$ & $\begin{array}{c}0.0198^{* *} \\
(0.00994)\end{array}$ & $\begin{array}{c}-0.00149 \\
(0.0128)\end{array}$ \\
\hline VIX & $\begin{array}{c}-0.0168^{* * *} \\
(0.00348)\end{array}$ & $\begin{array}{c}-0.0155^{* * *} \\
(0.00254)\end{array}$ & $\begin{array}{c}-0.0151^{* * *} \\
(0.00371)\end{array}$ & $\begin{array}{c}-0.0161^{* * *} \\
(0.00279)\end{array}$ & $\begin{array}{c}-0.0163^{* * *} \\
(0.00240)\end{array}$ & $\begin{array}{c}-0.0153^{* * *} \\
(0.00345)\end{array}$ & $\begin{array}{c}-0.0159^{* * *} * \\
(0.00282)\end{array}$ & $\begin{array}{c}-0.0163^{* * *} \\
(0.00245)\end{array}$ & $\begin{array}{c}-0.0151^{* * *} * \\
(0.00345)\end{array}$ \\
\hline Constant & $\begin{array}{c}0.316^{* * *} \\
(0.0763)\end{array}$ & $\begin{array}{c}0.418^{* * *} \\
(0.0690)\end{array}$ & $\begin{array}{c}0.264^{* * *} \\
(0.0828)\end{array}$ & $\begin{array}{c}0.383^{* * *} \\
(0.0729)\end{array}$ & $\begin{array}{c}0.442^{* * *} \\
(0.0653)\end{array}$ & $\begin{array}{c}0.310^{* * *} \\
(0.0808)\end{array}$ & $\begin{array}{c}0.382^{* * *} \\
(0.0718)\end{array}$ & $\begin{array}{c}0.438^{* * *} \\
(0.0675)\end{array}$ & $\begin{array}{c}0.310^{* * *} \\
(0.0792)\end{array}$ \\
\hline Sample & full & $\mathrm{AM}$ & EM & full & $\mathrm{AM}$ & EM & full & $\mathrm{AM}$ & EM \\
\hline Observations & 3,975 & 2,147 & 1,828 & 3,498 & 1,944 & 1,554 & 3,498 & 1,944 & 1,554 \\
\hline R-squared & 0.3286 & 0.4278 & 0.3531 & 0.4038 & 0.4704 & 0.3932 & 0.4053 & 0.4633 & 0.3958 \\
\hline Number of countries & 59 & 29 & 30 & 55 & 27 & 28 & 55 & 27 & 28 \\
\hline
\end{tabular}

Note: Driscoll-Kraay standard errors in parentheses. ${ }^{* * *} \mathrm{p}<0.01 ;{ }^{* *} \mathrm{p}<0.05 ;{ }^{*} \mathrm{p}<0.1$. 
cal to perfectly countercyclical, stock market-inflation responsiveness becomes more negative by 5.47 units. The estimated coefficient on expected inflation is -1.9 , which means if monetary policy is acyclical, one percentage point increase in the growth rate of expected inflation is correlated with a 1.9 percentage point decrease in the growth rate of real stock returns. This result echoes the theoretical findings of Bakshi and Chen (1996), as well as Boyle and Peterson (1995). In both advanced and emerging markets, real stock returns respond negatively to inflation and policy rate cyclicality, however the estimated effects of expected inflation and expected inflation interacted with policy rate cyclicality on real stock returns are larger in advanced markets than those in emerging markets. This may be due to better monetary policy transmission in advanced markets so that markets are more sensitive to policy cyclicality and rate changes. In addition to that, advanced markets have lower inflation compared to emerging markets, and therefore markets are more responsive to one unit of change in inflation. Lastly, regressions using interaction terms between inflation and countercyclical policy dummy yield similar results. In countries which pursue countercyclical monetary policies, real stock returns react more negatively to inflation.

Results here explain the puzzling differences of stock return-inflation dynamics in advanced and emerging markets. On the surface, the two income groups have experienced very distinct stock return-inflation patterns. Beneath the surface, the root of the problem partly lies in the cyclicality of monetary policy and the monetary policy transmission channels. Most advanced markets pursue countercyclical monetary policies. They have either adopted an inflation targeting framework or implicitly targeted inflation. Monetary aggregate as an intermediate variable has delinked from real economic activities, and central banks have considered M2 as a less important indicator. ${ }^{13}$ To the contrary, emerging markets are hindered by pursuing countercyclical monetary policies. In addition, emerging markets are undergoing changes in

action, but on market reaction. Including individual member countries in the Eurozone provides additional information on how markets react to inflation and monetary policy cyclicality. In the robustness check section, I re-run the regression by dropping the observations after countries joined the Eurozone.

${ }^{13}$ Adrian and Shin (2010) argue this has to do with the changing nature of financial intermediation in advanced markets. Before 1980, the monetary policy literature primarily focused on the role of monetary aggregates in the supply of credit. However, with the emergence of the market-based financial system, the ratio of high-powered money to total credit (the money multiplier) became highly unstable. As a consequence, monetary aggregates faded from both the policy debate and the monetary policy literature. 
the monetary policy frameworks, and a number of EMs are still under a monetary aggregates target framework.

\subsection{Results by Monetary Policy Framework}

This section further refines the results by monetary policy framework. Each year, the International Monetary Fund surveys central banks around the world and reports their de facto monetary policy framework in its Annual Report on Exchange Arrangements and Exchange Restrictions (AREAER). The AREAER database classifies countries' monetary policy framework into the following four categories: exchange rate anchor, monetary aggregate target, inflation targeting, and other frameworks.

We expect the stock return-inflation relation differ when the central banks target different nominal anchors. In particular, the exchange rate anchor and inflation targeting are two regimes of interest. They are two extreme cases of whether monetary policy responds directly to inflation or not. The conjecture is that if monetary policy solely focuses on stabilizing the exchange rate, policy cyclicality will not change how real stock returns react to inflation. On the other hand, if monetary policy targets inflation only, policy cyclicality will have strong and unintended consequences on market responses to inflation.

Results show that under exchange rate anchor regime, real stock returns do not respond to monetary policy cyclicality in both advanced and emerging markets ( $\mathrm{Ta}$ ble 4). Interaction terms between inflation and monetary policy cyclicality are not statistically significant. ${ }^{14}$ This may be due to the reason that markets clearly understand that stabilizing exchange rate is the sole objective of the central bank, so that the central bank will not respond directly to inflation movements. At the same time, the estimated coefficients of expected and unexpected inflation are negative and statistically significant. This means when inflation rises, real stock return decreases, suggesting that there are other frictions at work.

Among all monetary policy frameworks, inflation targeting is one interesting group, since the assumption is that markets should react more sharply to inflation if inflation is the sole explicitly stated nominal anchor in conducting monetary policy.

\footnotetext{
${ }^{14}$ The significance of the interaction term in Column (8) is driven by outliers, since only 2 out of 33 advanced markets do not pursue countercyclical monetary policies.
} 
Table 4: Regressions on Real Stock Returns by Monetary Policy Framework: Exchange Rate Anchor, 1990-2014

\begin{tabular}{|c|c|c|c|c|c|c|c|c|c|}
\hline Dependent variable: real stock return & (1) & (2) & (3) & (4) & (5) & (6) & (7) & (8) & (9) \\
\hline Expected inflation & $\begin{array}{c}-1.017^{* * *} \\
(0.256)\end{array}$ & $\begin{array}{c}-5.892^{* * *} \\
(1.202)\end{array}$ & $\begin{array}{c}-1.086^{* * *} \\
(0.277)\end{array}$ & $\begin{array}{c}-2.866^{* * *} \\
(0.621)\end{array}$ & $\begin{array}{l}-3.989^{*} \\
(2.265)\end{array}$ & $\begin{array}{c}-2.727^{* * *} \\
(0.593)\end{array}$ & $\begin{array}{c}-2.299^{* * *} \\
(0.724)\end{array}$ & $\begin{array}{c}2.565 \\
(2.120)\end{array}$ & $\begin{array}{c}-2.564^{* * *} \\
(0.727)\end{array}$ \\
\hline Unexpected inflation & $\begin{array}{c}-1.220^{* * *} \\
(0.389)\end{array}$ & $\begin{array}{c}-4.543^{* *} \\
(1.775)\end{array}$ & $\begin{array}{c}-1.329^{* * *} \\
(0.398)\end{array}$ & $\begin{array}{c}-3.099 * * * \\
(1.090)\end{array}$ & $\begin{array}{c}-6.202^{* * *} \\
(1.734)\end{array}$ & $\begin{array}{c}-2.813^{* *} \\
(1.224)\end{array}$ & $\begin{array}{c}-3.273^{* *} \\
(1.322)\end{array}$ & $\begin{array}{l}-2.828^{*} \\
(1.437)\end{array}$ & $\begin{array}{c}-3.228^{* *} \\
(1.466)\end{array}$ \\
\hline Expected inflation $\times$ policy rate cyclicality & & & & $\begin{array}{c}0.321 \\
(2.419)\end{array}$ & $\begin{array}{l}-4.809 \\
(4.570)\end{array}$ & $\begin{array}{c}2.662 \\
(2.380)\end{array}$ & & & \\
\hline Unexpected inflation $\times$ policy rate cyclicality & & & & $\begin{array}{c}2.208 \\
(2.457)\end{array}$ & $\begin{array}{c}6.317 \\
(4.079)\end{array}$ & $\begin{array}{c}3.345 \\
(2.736)\end{array}$ & & & \\
\hline Expected inflation $\times$ countercyclical policy dummy & & & & & & & $\begin{array}{l}-1.995 \\
(1.366)\end{array}$ & $\begin{array}{c}-9.920 * * * \\
(2.385)\end{array}$ & $\begin{array}{c}-0.568 \\
(1.400)\end{array}$ \\
\hline Unexpected inflation $\times$ countercyclical policy dummy & & & & & & & $\begin{array}{c}0.636 \\
(1.935)\end{array}$ & $\begin{array}{l}-0.363 \\
(2.862)\end{array}$ & $\begin{array}{c}1.314 \\
(2.180)\end{array}$ \\
\hline Industrial production growth rate & $\begin{array}{c}1.408^{* * *} \\
(0.197)\end{array}$ & $\begin{array}{c}1.391 * * * \\
(0.264)\end{array}$ & $\begin{array}{c}1.392^{* * * *} \\
(0.224)\end{array}$ & $\begin{array}{c}1.213^{* * *} \\
(0.139)\end{array}$ & $\begin{array}{c}1.130^{* * *} \\
(0.188)\end{array}$ & $\begin{array}{c}1.279^{* * *} \\
(0.180)\end{array}$ & $\begin{array}{c}1.228^{* * *} * \\
(0.138)\end{array}$ & $\begin{array}{c}1.117^{* * *} * \\
(0.182)\end{array}$ & $\begin{array}{c}1.284^{* * *} \\
(0.181)\end{array}$ \\
\hline M2 growth rate & $\begin{array}{c}0.983^{* * *} \\
(0.225)\end{array}$ & $\begin{array}{l}0.0724 \\
(0.377)\end{array}$ & $\begin{array}{c}1.061^{* * *} \\
(0.245)\end{array}$ & $\begin{array}{c}0.777^{* * *} \\
(0.211)\end{array}$ & $\begin{array}{c}0.317 \\
(0.394)\end{array}$ & $\begin{array}{c}0.875^{* * *} \\
(0.223)\end{array}$ & $\begin{array}{c}0.750^{* * *} \\
(0.208)\end{array}$ & $\begin{array}{c}0.344 \\
(0.370)\end{array}$ & $\begin{array}{c}0.838^{* * *} \\
(0.227)\end{array}$ \\
\hline Improvement in financial risk rating & $\begin{array}{c}0.0101 \\
(0.00941)\end{array}$ & $\begin{array}{c}-0.00795 \\
(0.0115)\end{array}$ & $\begin{array}{l}0.0195^{* *} \\
(0.00780)\end{array}$ & $\begin{array}{c}0.0128^{*} \\
(0.00714)\end{array}$ & $\begin{array}{c}-0.00613 \\
(0.0111)\end{array}$ & $\begin{array}{c}0.0186^{* *} \\
(0.00745)\end{array}$ & $\begin{array}{c}0.0122^{*} \\
(0.00703)\end{array}$ & $\begin{array}{c}-0.00700 \\
(0.0115)\end{array}$ & $\begin{array}{l}0.0183^{* *} \\
(0.00726)\end{array}$ \\
\hline U.S 3-month Treasury bill yield rate & $\begin{array}{c}-0.0357^{* * *} \\
(0.0128)\end{array}$ & $\begin{array}{c}-0.0164 \\
(0.0157)\end{array}$ & $\begin{array}{c}-0.0336^{* *} \\
(0.0141)\end{array}$ & $\begin{array}{l}-0.0171 \\
(0.0115)\end{array}$ & $\begin{array}{c}-0.0302^{*} \\
(0.0175)\end{array}$ & $\begin{array}{l}-0.0103 \\
(0.0138)\end{array}$ & $\begin{array}{l}-0.0164 \\
(0.0115)\end{array}$ & $\begin{array}{c}-0.0273^{*} \\
(0.0163)\end{array}$ & $\begin{array}{l}-0.00937 \\
(0.0141)\end{array}$ \\
\hline VIX & $\begin{array}{c}-0.0138^{* * *} \\
(0.00361)\end{array}$ & $\begin{array}{c}-0.0121 * * * \\
(0.00331)\end{array}$ & $\begin{array}{c}-0.0139^{* * *} \\
(0.00411)\end{array}$ & $\begin{array}{c}-0.0154^{* * *} * \\
(0.00323)\end{array}$ & $\begin{array}{c}-0.0156^{* * *} \\
(0.00319)\end{array}$ & $\begin{array}{c}-0.0149^{* * *} * \\
(0.00340)\end{array}$ & $\begin{array}{c}-0.0146^{* * *} \\
(0.00325)\end{array}$ & $\begin{array}{c}-0.0144^{* * *} \\
(0.00304)\end{array}$ & $\begin{array}{c}-0.0145^{* * * *} \\
(0.00349)\end{array}$ \\
\hline Constant & $\begin{array}{c}0.334^{* * *} \\
(0.0892)\end{array}$ & $\begin{array}{c}0.523 * * * \\
(0.0895)\end{array}$ & $\begin{array}{l}0.259^{* *} \\
(0.100)\end{array}$ & $\begin{array}{c}0.398^{* * *} \\
(0.0847)\end{array}$ & $\begin{array}{c}0.606^{* * *} \\
(0.0893)\end{array}$ & $\begin{array}{c}0.325^{* * *} \\
(0.0854)\end{array}$ & $\begin{array}{c}0.402^{* * *} \\
(0.0812)\end{array}$ & $\begin{array}{c}0.591^{* * *} \\
(0.0809)\end{array}$ & $\begin{array}{c}0.329^{* * *} \\
(0.0843)\end{array}$ \\
\hline Sample & full & $\mathrm{AM}$ & EM & full & $\mathrm{AM}$ & $\mathrm{EM}$ & full & $\mathrm{AM}$ & $\mathrm{EM}$ \\
\hline Observations & 871 & 370 & 501 & 603 & 211 & 392 & 603 & 211 & 392 \\
\hline R-squared & 0.3052 & 0.3648 & 0.3207 & 0.4311 & 0.4608 & 0.4506 & 0.4381 & 0.4999 & 0.4467 \\
\hline Number of countries & 40 & 20 & 20 & 27 & 11 & 16 & 27 & 11 & 16 \\
\hline
\end{tabular}

Note: Driscoll-Kraay standard errors in parentheses. ${ }^{* * *} \mathrm{p}<0.01 ;{ }^{* *} \mathrm{p}<0.05$; $^{*} \mathrm{p}<0.1$. 
Table 5: Regressions on Real Stock Returns by Monetary Policy Framework: Inflation Targeting, 1990-2014

\begin{tabular}{|c|c|c|c|c|c|c|c|c|c|}
\hline Dependent variable: real stock return & $(1)$ & $(2)$ & $(3)$ & $(4)$ & $(5)$ & $(6)$ & $(7)$ & $(8)$ & $(9)$ \\
\hline Expected inflation & $\begin{array}{c}-4.289^{* * *} \\
(1.000)\end{array}$ & $\begin{array}{c}-8.474^{* * *} \\
(2.032)\end{array}$ & $\begin{array}{c}-2.344^{* * *} \\
(0.800)\end{array}$ & $\begin{array}{c}-3.545^{* * *} \\
(0.784)\end{array}$ & $\begin{array}{c}-3.179^{* *} \\
(1.534)\end{array}$ & $\begin{array}{c}-2.386^{* * *} \\
(0.812)\end{array}$ & $\begin{array}{c}-3.020^{* * *} \\
(0.942)\end{array}$ & $\begin{array}{c}-5.543^{* * *} \\
(1.593)\end{array}$ & $\begin{array}{c}-2.452^{* *} \\
(1.071)\end{array}$ \\
\hline Unexpected inflation & $\begin{array}{c}-3.680^{* * *} \\
(0.694)\end{array}$ & $\begin{array}{c}-4.975^{* *} \\
(1.898)\end{array}$ & $\begin{array}{l}-2.592^{* * *} \\
(0.615)\end{array}$ & $\begin{array}{l}-3.022^{* * *} \\
(0.574)\end{array}$ & $\begin{array}{c}0.781 \\
(3.093)\end{array}$ & $\begin{array}{l}-2.686^{* * *} \\
(0.646)\end{array}$ & $\begin{array}{c}-2.663^{* *} \\
(1.048)\end{array}$ & $\begin{array}{l}-3.518 \\
(3.284)\end{array}$ & $\begin{array}{c}-2.452^{* *} \\
(1.089)\end{array}$ \\
\hline Expected inflation $\times$ policy rate cyclicality & & & & $\begin{array}{c}-4.510^{* *} \\
(2.219)\end{array}$ & $\begin{array}{c}-15.28^{* *} \\
(5.891)\end{array}$ & $\begin{array}{c}0.631 \\
(1.249)\end{array}$ & & & \\
\hline Unexpected inflation $\times$ policy rate cyclicality & & & & $\begin{array}{l}-3.833 \\
(2.337)\end{array}$ & $\begin{array}{c}-18.32^{* *} \\
(8.075)\end{array}$ & $\begin{array}{l}-1.309 \\
(1.491)\end{array}$ & & & \\
\hline Expected inflation $\times$ countercyclical policy dummy & & & & & & & $\begin{array}{l}-2.422^{*} \\
(1.375)\end{array}$ & $\begin{array}{l}-3.919 \\
(2.533)\end{array}$ & $\begin{array}{c}0.281 \\
(1.288)\end{array}$ \\
\hline Unexpected inflation $\times$ countercyclical policy dummy & & & & & & & $\begin{array}{l}-1.521 \\
(2.049)\end{array}$ & $\begin{array}{l}-1.457 \\
(4.225)\end{array}$ & $\begin{array}{l}-0.555 \\
(2.011)\end{array}$ \\
\hline Industrial production growth rate & $\begin{array}{c}0.967 * * * \\
(0.212)\end{array}$ & $\begin{array}{c}0.936^{* * *} \\
(0.216)\end{array}$ & $\begin{array}{c}1.139^{* * *} \\
(0.252)\end{array}$ & $\begin{array}{c}1.042^{* * *} \\
(0.219)\end{array}$ & $\begin{array}{c}1.240^{* * *} \\
(0.222)\end{array}$ & $\begin{array}{c}1.142^{* * *} \\
(0.254)\end{array}$ & $\begin{array}{c}1.001^{* * *} * \\
(0.219)\end{array}$ & $\begin{array}{c}0.977^{* * *} * \\
(0.229)\end{array}$ & $\begin{array}{c}1.140^{* * *} \\
(0.257)\end{array}$ \\
\hline M2 growth rate & $\begin{array}{l}-0.466 \\
(0.305)\end{array}$ & $\begin{array}{l}-0.534 \\
(0.503)\end{array}$ & $\begin{array}{l}-0.422^{*} \\
(0.232)\end{array}$ & $\begin{array}{l}-0.408 \\
(0.282)\end{array}$ & $\begin{array}{l}-0.348 \\
(0.415)\end{array}$ & $\begin{array}{c}-0.426^{*} \\
(0.236)\end{array}$ & $\begin{array}{l}-0.428 \\
(0.293)\end{array}$ & $\begin{array}{l}-0.448 \\
(0.482)\end{array}$ & $\begin{array}{c}-0.423^{*} \\
(0.230)\end{array}$ \\
\hline Improvement in financial risk rating & $\begin{array}{l}0.0125^{* *} \\
(0.00478)\end{array}$ & $\begin{array}{c}0.00316 \\
(0.00723)\end{array}$ & $\begin{array}{c}0.0180^{* * *} * \\
(0.00559)\end{array}$ & $\begin{array}{c}0.0126 * * * \\
(0.00474)\end{array}$ & $\begin{array}{c}0.00154 \\
(0.00643)\end{array}$ & $\begin{array}{c}0.0182^{* * *} \\
(0.00546)\end{array}$ & $\begin{array}{l}0.0120 * * \\
(0.00464)\end{array}$ & $\begin{array}{c}0.00164 \\
(0.00731)\end{array}$ & $\begin{array}{c}0.0182 * * * \\
(0.00557)\end{array}$ \\
\hline U.S 3-month Treasury bill yield rate & $\begin{array}{c}0.0151 \\
(0.0124)\end{array}$ & $\begin{array}{c}0.0205 \\
(0.0141)\end{array}$ & $\begin{array}{l}0.00806 \\
(0.0143)\end{array}$ & $\begin{array}{c}0.0152 \\
(0.0122)\end{array}$ & $\begin{array}{c}0.0191 \\
(0.0128)\end{array}$ & $\begin{array}{l}0.00813 \\
(0.0144)\end{array}$ & $\begin{array}{c}0.0159 \\
(0.0123)\end{array}$ & $\begin{array}{c}0.0222 \\
(0.0140)\end{array}$ & $\begin{array}{l}0.00809 \\
(0.0144)\end{array}$ \\
\hline VIX & $\begin{array}{c}-0.0137^{* * *} \\
(0.00248)\end{array}$ & $\begin{array}{c}-0.0123^{* * *} \\
(0.00202)\end{array}$ & $\begin{array}{c}-0.0137^{* * *} \\
(0.00300)\end{array}$ & $\begin{array}{c}-0.0132 * * * \\
(0.00241)\end{array}$ & $\begin{array}{c}-0.0125^{* * *} \\
(0.00200)\end{array}$ & $\begin{array}{c}-0.0137^{* * *} \\
(0.00308)\end{array}$ & $\begin{array}{c}-0.0134^{* * *} \\
(0.00247)\end{array}$ & $\begin{array}{c}-0.0124^{* * *} \\
(0.00204)\end{array}$ & $\begin{array}{c}-0.0137^{* * *} * \\
(0.00315)\end{array}$ \\
\hline Constant & $\begin{array}{c}0.477^{* * *} \\
(0.0913)\end{array}$ & $\begin{array}{c}0.476^{* * *} \\
(0.0830)\end{array}$ & $\begin{array}{c}0.442^{* * *} \\
(0.0907)\end{array}$ & $\begin{array}{c}0.463^{* * *} \\
(0.0861)\end{array}$ & $\begin{array}{c}0.488^{* * *} \\
(0.0807)\end{array}$ & $\begin{array}{c}0.443^{* * *} \\
(0.0928)\end{array}$ & $\begin{array}{c}0.466^{* * *} \\
(0.0875)\end{array}$ & $\begin{array}{c}0.480^{* * *} \\
(0.0859)\end{array}$ & $\begin{array}{c}0.443 * * * \\
(0.0936)\end{array}$ \\
\hline Sample & full & $\mathrm{AM}$ & EM & full & $\mathrm{AM}$ & EM & full & $\mathrm{AM}$ & $\mathrm{EM}$ \\
\hline Observations & 1,214 & 564 & 650 & 1,202 & 552 & 650 & 1,202 & 552 & 650 \\
\hline R-squared & 0.409 & 0.4843 & 0.403 & 0.424 & 0.5388 & 0.4038 & 0.4191 & 0.5043 & 0.4033 \\
\hline Number of countries & 30 & 14 & 16 & 29 & 13 & 16 & 29 & 13 & 16 \\
\hline
\end{tabular}

Note: Driscoll-Kraay standard errors in parentheses. ${ }^{* * *} \mathrm{p}<0.01 ;{ }^{* *} \mathrm{p}<0.05$; $^{*} \mathrm{p}<0.1$ 

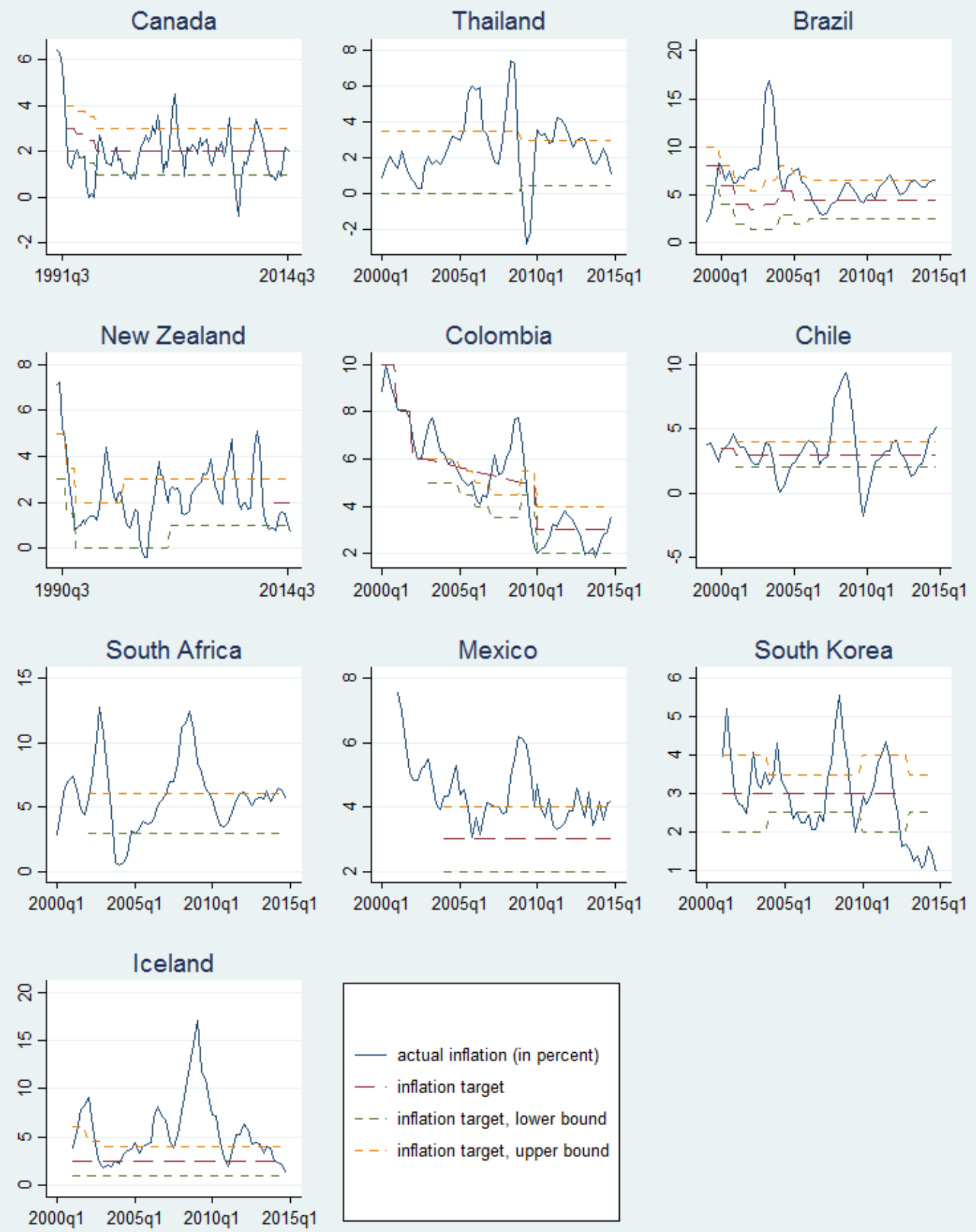

Figure 6: Performance of Inflation Targeting Countries: Top Group 

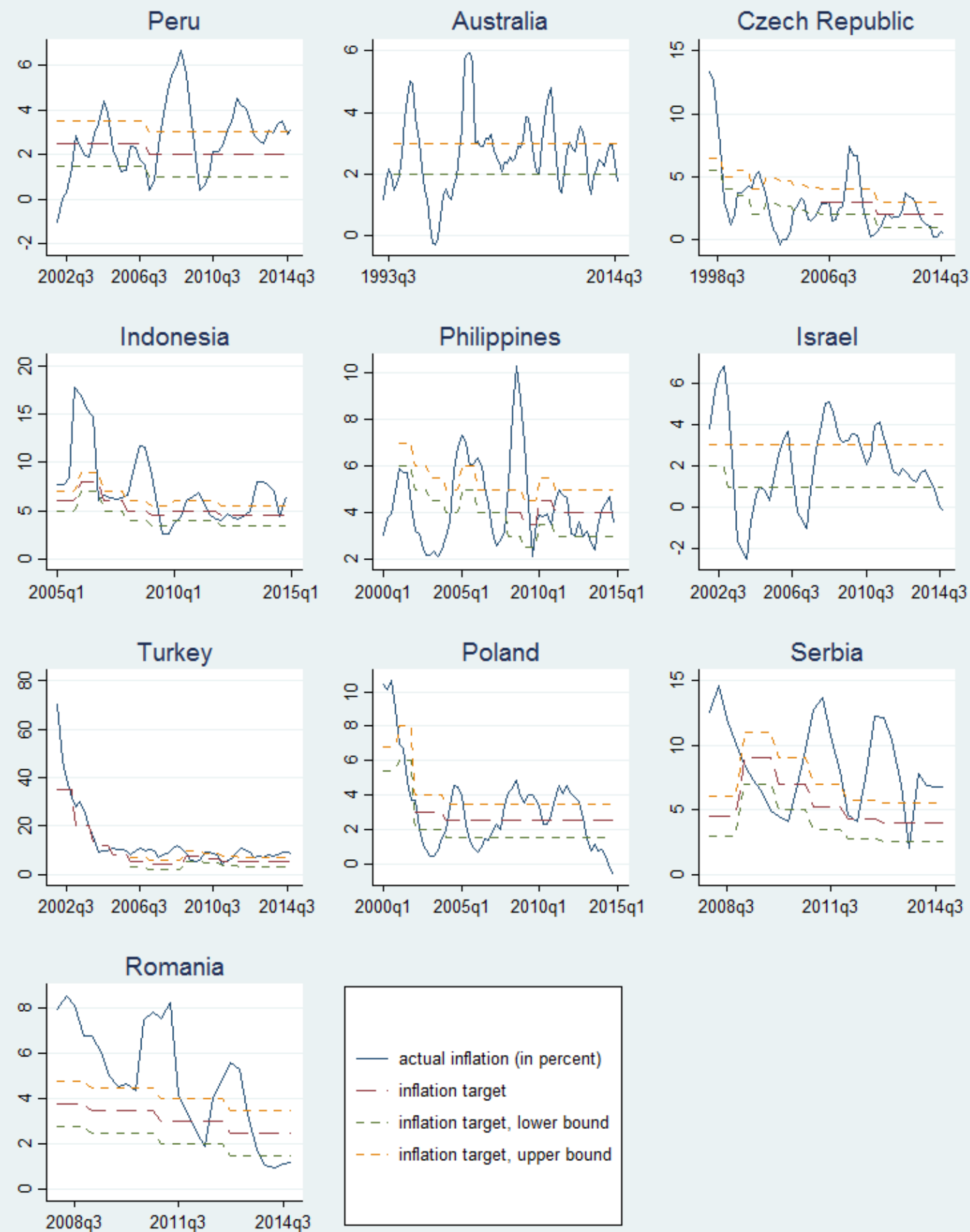

Figure 7: Performance of Inflation Targeting Countries: Bottom Group 
Table 6: Performance of Inflation Targeting Countries: Percent of Time Inflation within the Announced Range

\begin{tabular}{cccc}
\hline Top inflation targeters & \multicolumn{3}{c}{ Bottom inflation targeters } \\
\hline Canada & $70 \%$ & Peru & $44 \%$ \\
Thailand & $65 \%$ & Australia & $40 \%$ \\
Brazil & $64 \%$ & Czech Republic & $40 \%$ \\
New Zealand & $61 \%$ & Indonesia & $38 \%$ \\
Colombia & $60 \%$ & Philippines & $38 \%$ \\
Chile & $57 \%$ & Israel & $35 \%$ \\
South Africa & $50 \%$ & Turkey & $28 \%$ \\
Mexico & $48 \%$ & Poland & $27 \%$ \\
South Korea & $46 \%$ & Serbia & $18 \%$ \\
Iceland & $46 \%$ & Romania & $18 \%$ \\
\hline
\end{tabular}

Results from Table 5 indicate that the assumption is well-grounded. For inflation targeting countries, the results are more pronounced, compared to the baseline result. When only inflation targeting countries are considered, the estimated effects are larger and statistically more significant. On average, real stock returns respond more negatively to expected and unexpected inflation, and this is true in both advanced and emerging markets. When the interaction terms between inflation and policy rate cyclicality are included, the estimated coefficients are extremely negative and statistically significant for advanced markets, but not for emerging markets. This may reflect the fact that the credibility of the central banks differ in advanced and emerging markets.

To understand why stock returns do not respond to monetary policy cyclicality in emerging market inflation targeters, I further explore central banks' track record of controlling inflation by examining inflation performance with respect to central banks' inflation target bands. While many central banks target medium-term inflation and no central bank intends to keep inflation within the announced band at every point in time, a persistent period of inflation falling outside the target band raises concerns about a central bank's capacity and credibility in controlling inflation. My approach to classify inflation targeting countries is similar to the idea of coding countries by their de facto exchange rate regime. To the extent of my knowledge, no academic study has done such exercise before. Among the 30 inflation targeting countries in the sample, 24 of them have more than 5 years of experience, and 20 of them have 
Table 7: Regressions on Real Stock Returns by Monetary Policy Framework: Inflation Targeting, Continued.

\begin{tabular}{|c|c|c|c|c|c|c|c|c|c|}
\hline Dependent variable: real stock return & $(1)$ & $(2)$ & $(3)$ & $(4)$ & $(5)$ & $(6)$ & $(7)$ & $(8)$ & $(9)$ \\
\hline Expected inflation & $\begin{array}{c}-2.506^{* * *} \\
(0.866)\end{array}$ & $\begin{array}{c}-3.743^{* * *} \\
(0.865)\end{array}$ & $\begin{array}{c}-2.066^{* *} \\
(0.977)\end{array}$ & $\begin{array}{c}-3.675^{* * *} \\
(0.935)\end{array}$ & $\begin{array}{l}-1.746 \\
(1.287)\end{array}$ & $\begin{array}{c}-3.645^{* * *} \\
(0.942)\end{array}$ & $\begin{array}{l}-0.984 \\
(2.402)\end{array}$ & $\begin{array}{l}-0.888 \\
(5.557)\end{array}$ & $\begin{array}{l}-0.548 \\
(1.362)\end{array}$ \\
\hline Unexpected inflation & $\begin{array}{c}-2.912^{* * *} \\
(0.856)\end{array}$ & $\begin{array}{c}-3.390 * * * \\
(0.591)\end{array}$ & $\begin{array}{l}-1.704 \\
(1.362)\end{array}$ & $\begin{array}{c}-3.882^{* * *} \\
(0.755)\end{array}$ & $\begin{array}{l}-0.541 \\
(1.685)\end{array}$ & $\begin{array}{c}-3.812^{* * *} \\
(1.326)\end{array}$ & $\begin{array}{l}0.0113 \\
(2.995)\end{array}$ & $\begin{array}{c}5.859 \\
(4.990)\end{array}$ & $\begin{array}{c}-3.897^{* *} \\
(1.843)\end{array}$ \\
\hline Expected inflation $\times$ policy rate cyclicality & $\begin{array}{c}0.628 \\
(1.379)\end{array}$ & $\begin{array}{c}-4.278^{*} \\
(2.450)\end{array}$ & $\begin{array}{c}-11.51^{* *} \\
(4.539)\end{array}$ & $\begin{array}{c}0.385 \\
(1.621)\end{array}$ & & & $\begin{array}{l}-3.543 \\
(8.354)\end{array}$ & $\begin{array}{c}3.347 \\
(13.07)\end{array}$ & $\begin{array}{c}-25.13^{* * * *} \\
(5.278)\end{array}$ \\
\hline Unexpected inflation $\times$ policy rate cyclicality & $\begin{array}{l}-1.550 \\
(1.937)\end{array}$ & $\begin{array}{l}-4.016 \\
(2.581)\end{array}$ & $\begin{array}{c}-10.18^{* *} \\
(4.952)\end{array}$ & $\begin{array}{l}-1.520 \\
(1.750)\end{array}$ & & & $\begin{array}{l}-7.596 \\
(8.925)\end{array}$ & $\begin{array}{c}3.035 \\
(14.12)\end{array}$ & $\begin{array}{c}-17.15^{* *} \\
(7.337)\end{array}$ \\
\hline Exp. inflation $\times$ countercyclical policy dummy & & & & & $\begin{array}{c}-5.088^{* *} \\
(2.478)\end{array}$ & $\begin{array}{l}-0.181 \\
(1.087)\end{array}$ & & & \\
\hline Une. inflation $\times$ countercyclical policy dummy & & & & & $\begin{array}{l}-5.644^{*} \\
(3.237)\end{array}$ & $\begin{array}{l}0.0974 \\
(2.010)\end{array}$ & & & \\
\hline Industrial production growth rate & $\begin{array}{c}1.085^{* * *} \\
(0.275)\end{array}$ & $\begin{array}{c}1.140^{* * *} \\
(0.240)\end{array}$ & $\begin{array}{c}1.218^{* * *} \\
(0.188)\end{array}$ & $\begin{array}{c}0.987^{* *} \\
(0.400)\end{array}$ & $\begin{array}{c}1.143^{* * *} \\
(0.194)\end{array}$ & $\begin{array}{c}0.980^{* *} \\
(0.399)\end{array}$ & $\begin{array}{c}1.455^{* * *} \\
(0.261)\end{array}$ & $\begin{array}{c}1.302^{* * *} \\
(0.415)\end{array}$ & $\begin{array}{c}1.449^{* * *} \\
(0.464)\end{array}$ \\
\hline M2 growth rate & $\begin{array}{l}-0.254 \\
(0.217)\end{array}$ & $\begin{array}{l}-0.430 \\
(0.296)\end{array}$ & $\begin{array}{l}-0.570 \\
(0.479)\end{array}$ & $\begin{array}{l}-0.237 \\
(0.187)\end{array}$ & $\begin{array}{l}-0.606 \\
(0.512)\end{array}$ & $\begin{array}{l}-0.232 \\
(0.184)\end{array}$ & $\begin{array}{c}0.224 \\
(0.258)\end{array}$ & $\begin{array}{c}-1.506^{* * *} \\
(0.475)\end{array}$ & $\begin{array}{l}-0.924 \\
(0.566)\end{array}$ \\
\hline Improvement in financial risk rating & $\begin{array}{c}0.0193 * * * \\
(0.00572)\end{array}$ & $\begin{array}{c}0.0172^{* * * *} \\
(0.00504)\end{array}$ & $\begin{array}{l}0.0135^{* *} \\
(0.00656)\end{array}$ & $\begin{array}{c}0.0174 * \\
(0.00968)\end{array}$ & $\begin{array}{c}0.0134^{*} \\
(0.00719)\end{array}$ & $\begin{array}{c}0.0172^{*} \\
(0.00969)\end{array}$ & $\begin{array}{c}0.0264 * * * \\
(0.00652)\end{array}$ & $\begin{array}{c}0.0436^{* *} \\
(0.0207)\end{array}$ & $\begin{array}{l}-0.00714 \\
(0.00666)\end{array}$ \\
\hline U.S 3-month Treasury bill yield rate & $\begin{array}{c}0.0109 \\
(0.0147)\end{array}$ & $\begin{array}{c}0.0164 \\
(0.0129)\end{array}$ & $\begin{array}{c}0.0204 \\
(0.0127)\end{array}$ & $\begin{array}{l}0.00786 \\
(0.0173)\end{array}$ & $\begin{array}{c}0.0216 \\
(0.0132)\end{array}$ & $\begin{array}{l}0.00818 \\
(0.0172)\end{array}$ & $\begin{array}{c}0.0187 \\
(0.0137)\end{array}$ & $\begin{array}{r}-0.00126 \\
(0.0170)\end{array}$ & $\begin{array}{c}0.0167 \\
(0.0218)\end{array}$ \\
\hline VIX & $\begin{array}{c}-0.0118^{* * *} \\
(0.00272)\end{array}$ & $\begin{array}{c}-0.0125^{* * *} \\
(0.00262)\end{array}$ & $\begin{array}{c}-0.00882^{* * *} \\
(0.00196)\end{array}$ & $\begin{array}{c}-0.0171^{* * *} \\
(0.00414)\end{array}$ & $\begin{array}{c}-0.00916^{* * *} \\
(0.00200)\end{array}$ & $\begin{array}{c}-0.0170 * * * \\
(0.00414)\end{array}$ & $\begin{array}{c}-0.00845^{* * * *} \\
(0.00269)\end{array}$ & $\begin{array}{l}-0.00395 \\
(0.00556)\end{array}$ & $\begin{array}{c}-0.00856^{* * *} \\
(0.00271)\end{array}$ \\
\hline Constant & $\begin{array}{c}0.408^{* * *} \\
(0.0819)\end{array}$ & $\begin{array}{c}0.470^{* * *} \\
(0.0910)\end{array}$ & $\begin{array}{c}0.424^{* * *} \\
(0.0857)\end{array}$ & $\begin{array}{c}0.511^{* * *} \\
(0.104)\end{array}$ & $\begin{array}{c}0.439^{* * *} \\
(0.0932)\end{array}$ & $\begin{array}{c}0.512^{* * *} \\
(0.105)\end{array}$ & $\begin{array}{c}0.241^{* *} \\
(0.110)\end{array}$ & $\begin{array}{c}0.297^{* *} \\
(0.113)\end{array}$ & $\begin{array}{c}0.590^{* * *} \\
(0.112)\end{array}$ \\
\hline Sample & $\begin{array}{l}\text { Long-term } \\
\text { EM IT }\end{array}$ & $\begin{array}{c}\text { all IT } \\
\mathrm{w} / \text { band }\end{array}$ & $\begin{array}{l}\text { top IT } \\
\text { in band }\end{array}$ & $\begin{array}{l}\text { bottom IT } \\
\text { in band }\end{array}$ & $\begin{array}{l}\text { top IT } \\
\text { in band }\end{array}$ & $\begin{array}{l}\text { bottom IT } \\
\text { in band }\end{array}$ & $\begin{array}{c}\text { top IT } \\
\pi \text { within range }\end{array}$ & $\begin{array}{c}\text { top IT } \\
\pi \text { below range }\end{array}$ & $\begin{array}{c}\text { top IT } \\
\pi \text { above range }\end{array}$ \\
\hline Observations & 558 & 918 & 530 & 388 & 530 & 388 & 292 & 57 & 153 \\
\hline R-squared & 0.3966 & 0.4287 & 0.4599 & 0.4544 & 0.4287 & 0.4537 & 0.3585 & 0.3994 & 0.6359 \\
\hline Number of countries & 11 & 18 & 9 & 9 & 9 & 9 & 9 & 7 & 9 \\
\hline
\end{tabular}

Note: Driscoll-Kraay standard errors in parentheses. ${ }^{* * *} \mathrm{p}<0.01 ;{ }^{* *} \mathrm{p}<0.05 ;{ }^{*} \mathrm{p}<0.1$. 
announced explicit inflation bands to the public. I divide these 20 countries into two groups based on the percent of time inflation remains in the range announced by the central bank (Figures 6 and 7). ${ }^{15}$ The results are reported in Table 6 and they reveal staggering differences in central banks' tendency in managing inflation. ${ }^{16}$ Canada as the top performer keeps inflation within the target band for $70 \%$ of the time. On the other hand, the central bank in Romania has faced overwhelming difficulties in steering inflation towards their target band and as a result inflation is within the announced range for only $18 \%$ of the period. The threshold is $45 \%$ to separate the sample into top and bottom groups. Results in Column 1 of Table 7 shows that emerging market inflation targeters with more than 10 years of experience in general are not successful in shaping market perceptions. It is the history of inflation targeting record rather than the length of the record that matters. Announcing the inflation band helps a little bit in shaping market perceptions, as shown in Column 2. Furthermore, markets are reacting to monetary policy cyclicality in the top group, but not so in the bottom group. This means that central banks' ability to maintain inflation within their target bans is key to shape market perceptions.

The inflation targeting countries in the top group, which include both advanced and emerging markets, maintain inflation within their target bands most of the time, and markets pay attention to monetary policy cyclicality. Instead, the inflation targeting countries in the bottom group are struggling to keep inflation in the announced bands. As a result, markets do not pay much attention to monetary policy cyclicality. ${ }^{17}$

\footnotetext{
${ }^{15}$ In reality, this calculation is complicated by the fact that central banks use different underlying inflation measures (for example, headline CPI vs. core CPI), various target horizons (1 year or mid-term), revisions in targets at certain points in time, and adjustments made by authorities to account for structural breaks such as one-off tax changes. Nevertheless, given the nature of the study, and the way countries are grouped into two categories, this approach illustrates the point of central bank credibility and capability, and serves the purpose well.

${ }^{16}$ It is worth noting idiosyncrasies in inflation targeting bands in different countries. Certain countries have set themselves more difficult tasks due to tighter bands. For instance, Australia's inflation target band is 1 percentage point wide (2-3 percent), while Canada's is 2 percentage points wide (1-3 percent). If Australia's target range had instead been a 2 percentage points, we would have seen a higher share of the time within that range for Australia. Nevertheless, this paper adopts a fact-based approach that only uses central banks' official inflation bands to assess inflation targeting countries.

${ }^{17}$ Ilzetzki, Reinhart and Rogoff (2017) make a similar argument that inflation targeting countries are heterogeneous and far less distinctive as one group than advertised. Using event studies and estimating an augmented Taylor rule for the inflation targeting group, they show that inflation targeting central banks differ in the degree of stabilzing inflation and managing exchange rates.
} 
Finally, for the top inflation targeters, I split the results by looking at scenarios when inflation is within, below or above the target band. In these countries, when inflation is outside the target band, it is three times more likely to see inflation is above the band (153 observations in regression) than inflation is below the band (57 observations in regression). Regression results indicate that the interaction terms are extremely significant when inflation is above the range, but they are not significant when inflation is within or below the range. This echoes the fact that historically, central banks are more concerned with inflation above the band and react asymmetrically to inflation dynamics with respect to the target. For the top inflation targeting countries with relative successful experience, markets learn from history and are most sensitive when inflation is above the range, but are unresponsive when inflation is within or below the range.

\subsection{Results with Respect to the Zero Lower Bound (ZLB)}

Lastly, I explore whether the stock return-inflation relation changes when monetary policy is constrained by the Zero Lower Bound. The onset of the Global Financial Crisis (GFC) has prompted central banks around the world to lower their policy rates, and policy rates in a number of countries have hit the Zero Lower Bound. These countries include the United States, the Euro Area economies, Switzerland, Japan and several others. A natural question to ask is whether real stock returns still respond negatively to inflation, if the Zero Lower Bound is binding. To formally analyze this question, I run the following regression:

$Y_{i, t}=\beta_{0}+\beta_{1} \pi_{i, t}(1-Z L B)+\beta_{2} \pi_{i, t} Z L B+\beta_{3} \pi_{i, t} C_{i}(1-Z L B)+\beta_{4} \pi_{i, t} C_{i} Z L B+Z \Gamma+u_{i}+\epsilon_{i, t}$,

here I use actual inflation in the regression and interact it with a ZLB dummy variable. When $\mathrm{ZLB}=1$, policy rate is hindered by the ZLB. A Zero Lower Bound (ZLB) episode is identified if policy rate is below or equal to 25 basis points for a given country. The conjecture for this regression is that real stock returns respond asymmetrically to inflation and monetary policy cyclicality, depending on whether policy rate hits the Zero Lower Bound or not, and real stock returns respond the 
Table 8: Regressions on Real Stock Returns with Respect to the Zero Lower Bound (ZLB)

\begin{tabular}{|c|c|c|c|c|c|c|}
\hline Dependent variable: real stock return & (1) & $(2)$ & (3) & (4) & $(5)$ & (6) \\
\hline Inflation $\times(1-$ ZLB $)$ & $\begin{array}{c}-1.459^{* * *} \\
(0.339)\end{array}$ & $\begin{array}{c}-5.808^{* * *} \\
(0.905)\end{array}$ & $\begin{array}{c}-1.792^{* * *} \\
(0.313)\end{array}$ & $\begin{array}{c}-2.522^{* * *} \\
(0.835)\end{array}$ & $\begin{array}{c}-0.808^{* * *} \\
(0.251)\end{array}$ & $\begin{array}{l}-2.588 \\
(1.602)\end{array}$ \\
\hline Inflation $\times$ ZLB & $\begin{array}{l}-1.431 \\
(1.511)\end{array}$ & $\begin{array}{l}-0.365 \\
(2.174)\end{array}$ & $\begin{array}{l}-3.027 \\
(1.945)\end{array}$ & $\begin{array}{c}5.699 \\
(7.864)\end{array}$ & $\begin{array}{l}-4.476^{*} \\
(2.287)\end{array}$ & $\begin{array}{c}8.354 \\
(9.471)\end{array}$ \\
\hline Inflation $\times(1-$ ZLB $) \times$ policy rate cyclicality & & & $\begin{array}{c}-4.871^{* * *} \\
(0.879)\end{array}$ & $\begin{array}{c}-7.215^{* * *} \\
(1.734)\end{array}$ & & \\
\hline Inflation $\times$ ZLB $\times$ policy rate cyclicality & & & $\begin{array}{c}2.034 \\
(3.423)\end{array}$ & $\begin{array}{l}-13.09 \\
(11.36)\end{array}$ & & \\
\hline Inflation $\times(1-$ ZLB $) \times$ countercyclical policy dummy & & & & & $\begin{array}{c}-4.044^{* * *} \\
(0.659)\end{array}$ & $\begin{array}{c}-3.472^{*} \\
(1.807)\end{array}$ \\
\hline Inflation $\times$ ZLB $\times$ countercyclical policy dummy & & & & & $\begin{array}{c}3.601 \\
(3.099)\end{array}$ & $\begin{array}{l}-8.990 \\
(10.28)\end{array}$ \\
\hline Industrial production growth rate & $\begin{array}{c}1.178^{* * *} \\
(0.166)\end{array}$ & $\begin{array}{c}0.905^{* * *} \\
(0.183)\end{array}$ & $\begin{array}{c}1.215^{* * *} \\
(0.170)\end{array}$ & $\begin{array}{c}0.961^{* * *} \\
(0.182)\end{array}$ & $\begin{array}{c}1.220^{* * *} \\
(0.164)\end{array}$ & $\begin{array}{c}0.914^{* * *} \\
(0.187)\end{array}$ \\
\hline M2 growth rate & $\begin{array}{c}0.383^{* *} \\
(0.186)\end{array}$ & $\begin{array}{r}-0.0220 \\
(0.289)\end{array}$ & $\begin{array}{c}0.406^{* *} \\
(0.193)\end{array}$ & $\begin{array}{c}0.00554 \\
(0.275)\end{array}$ & $\begin{array}{c}0.386^{* *} \\
(0.194)\end{array}$ & $\begin{array}{c}-0.00864 \\
(0.288)\end{array}$ \\
\hline Improvement in financial risk rating & $\begin{array}{c}0.0132^{* * *} \\
(0.00502)\end{array}$ & $\begin{array}{l}0.000739 \\
(0.00573)\end{array}$ & $\begin{array}{l}0.0122^{* *} \\
(0.00497)\end{array}$ & $\begin{array}{l}0.000924 \\
(0.00559)\end{array}$ & $\begin{array}{l}0.0117^{* *} \\
(0.00490)\end{array}$ & $\begin{array}{l}0.000793 \\
(0.00582)\end{array}$ \\
\hline U.S 3-month Treasury bill yield rate & $\begin{array}{c}0.00453 \\
(0.0108)\end{array}$ & $\begin{array}{c}0.0220^{* *} \\
(0.0109)\end{array}$ & $\begin{array}{l}0.00947 \\
(0.0106)\end{array}$ & $\begin{array}{c}0.0211^{* *} \\
(0.0104)\end{array}$ & $\begin{array}{c}0.0105 \\
(0.0103)\end{array}$ & $\begin{array}{c}0.0221^{* *} \\
(0.0108)\end{array}$ \\
\hline VIX & $\begin{array}{c}-0.0169 * * * \\
(0.00316)\end{array}$ & $\begin{array}{c}-0.0165^{* * *} \\
(0.00273)\end{array}$ & $\begin{array}{c}-0.0163^{* * *} \\
(0.00293)\end{array}$ & $\begin{array}{c}-0.0166^{* * *} \\
(0.00269)\end{array}$ & $\begin{array}{c}-0.0161^{* * *} \\
(0.00293)\end{array}$ & $\begin{array}{c}-0.0167^{* * *} * \\
(0.00272)\end{array}$ \\
\hline Constant & $\begin{array}{c}0.360^{* * *} \\
(0.0809)\end{array}$ & $\begin{array}{c}0.415^{* * *} \\
(0.0723)\end{array}$ & $\begin{array}{c}0.376^{* * *} \\
(0.0756)\end{array}$ & $\begin{array}{c}0.426^{* * *} \\
(0.0703)\end{array}$ & $\begin{array}{c}0.375^{* * *} \\
(0.0741)\end{array}$ & $\begin{array}{c}0.417^{* * *} \\
(0.0721)\end{array}$ \\
\hline Sample & full & $\mathrm{AM}$ & full & $\mathrm{AM}$ & full & $\mathrm{EM}$ \\
\hline Observations & 3,663 & 1,945 & 3,498 & 1,944 & 3,498 & 1,944 \\
\hline R-squared & 0.3708 & 0.4484 & 0.4002 & 0.4587 & 0.4036 & 0.4512 \\
\hline Number of countries & 57 & 27 & 55 & 27 & 55 & 27 \\
\hline
\end{tabular}


same to other control variables.

By comparing stock market reactions under normal times and the Zero Lower Bound periods, we find an interesting phenomenon (Table 8). In normal times, when the Zero Lower Bound does not bind, we observe the conventional relationship: real stock returns respond negatively to inflation, and stock returns react more negatively to inflation when monetary policy becomes more countercyclical. For the periods when monetary policy is restricted by the ZLB, the estimated coefficients on inflation, and the interaction terms between inflation and monetary policy cyclicality measures are no longer significant. This means we cannot reject that real stock returns do not respond to inflation and monetary policy cyclicality under ZLB episodes. When it comes to inflation dynamics, stock markets seem to perceive the Zero Lower Bound as a different regime. The fact that inflation is usually low under the Zero Lower Bound indicates that a positive inflation surprise is good news, because the real interest rate is lower and the central bank does not need to respond to the upside inflation development. If there is a negative inflation surprise, there will be additional costs if the central bank decreases the policy rate and policymakers may be more reluctant to lower the rate. In addition, a possible Effective Lower Bound (ELB), where the central bank can no longer decrease its policy rate to stimulate the economy, is potentially noted by markets as well.

Nevertheless, since the Zero Lower Bound is a new phenomenon for most countries, the limited number of observations and low statistical power suggests that the readers need to interpret the results with caution. Indeed, the standard errors are much larger under the Zero Lower Bound episodes. The analysis here primarily focuses on advanced markets since there are very few Zero Lower Bound episodes for emerging markets. $^{18}$

\section{Robustness Check}

I have done the following robustness checks: re-run the augmented regression using actual inflation and test whether the stock return-inflation relation is less negative in

\footnotetext{
${ }^{18}$ Only three emerging markets in Eastern Europe (Bulgaria, Latvia and Lithuania.) have hit the Zero Lower Bound in recent years.
} 
emerging markets. A dummy variable for emerging market is interacted with actual inflation, and the interaction term is positive and statistically significant; drop the observations when countries adopted the Euro. When countries join the Eurozone, they lose monetary autonomy. Excluding such observations in a currency union allows us to investigate market reactions to domestic monetary policy; exclude hyperinflation periods. Drop observations with inflation higher $50 \%$ or $100 \%$ in the regression; use Consensus Forecasts data as measures of expected inflation; construct a global stock return factor by aggregating stock returns in Systemic-5 countries (United States, United Kingdom, Germany, Japan and China, weighted by nominal GDP) and include it as a control variable. The global factor is statistically significant, which means that stock returns in systemic countries is highly correlated with domestic market performance; replace the U.S. Treasury bill yield with Wu-Xia shadow federal funds rate to account for the issue of unconventional monetary policy at the Zero Lower Bound in the United States. The results remain mostly the same and they are reported in the appendix.

There are several limitations in this paper. First, the monetary policy cyclicality measure is computed as a constant throughout the sample period for a given country. Since monetary policy cyclicality could vary over time, this is a coarse measure. Results may be affected, especially when dividing countries by monetary policy framework, which is evolving as well. One potential improvement is to make policy rate cyclicality time-varying by decade.

The second caveat is regarding the inflation expectation measure. This paper defines inflation expectation based on forecasts from surveys or models. Conceptually, inflation forecast is not exactly the same as inflation expectation. However, because inflation expectations are not known in general, the inflation forecasts are the best measures available for many countries for a long period of time. Market-based measures of inflation expectations, such as estimates of inflation compensation embedded in the returns of financial instruments, are only available for a limited set of countries in recent years.

Lastly, the issue of cross-border listings and multinational firms blurs the boundaries of national stock returns. For example, a Chinese company chooses its Initial Public Offering (IPO) in Nasdaq runs most of its businesses outside the U.S., or a multinational corporation listed in the New York Stock Exchange receives most of its 
revenues from abroad. When such companies are included as component stocks, the underlying indices no longer perfectly represent national economic activities. Given these cases happen primarily in advanced countries and this paper studies 71 economies, the problem will not change the results substantially or qualitatively.

\section{Discussion and Conclusion}

As major central banks are conducting reviews on monetary policy frameworks and tools, this paper finds that how a central bank reacts to inflation plays a critical role in determining the stock return-inflation relation. In August 2020, the Federal Reserve announced a revision to its monetary policy framework by setting an Average Inflation Target (AIT) of 2 percent over the long-run, allowing for a period of abovethe-target inflation to offset low inflation in the past decade. The European Central Bank has replaced its inflation target of below but close to 2 percent with a symmetric target of 2 percent over the medium term. These changes will have implications on the stock return-inflation relation in the future.

This paper contributes to the stock return-inflation literature by examining how monetary policy shapes the stock return-inflation relation using a novel dataset of 71 advanced and emerging markets. The empirical results support the view that the stock return-inflation relation is partially driven by monetary policy cyclicality. If a country's central bank pursues a more countercyclical monetary policy, the stock return-inflation relation becomes more negative. The results highlight how the market anticipates monetary policy under a variety of regimes with implications for policy under exchange rate pegs, inflation targeting and the Zero Lower Bound (Figure 8).

Results suggest that central banks' decisions on policy cyclicality and the instruments employed in the toolkit not only affect real economic activities, but also result in a shift in the response of stock prices to inflation developments. Although the issue of whether monetary policy should respond to asset prices is still under debate, stock price fluctuations, especially the ones caused by monetary policy, deserve attention. In advanced markets, the Global Financial Crisis has prompted major central banks lowered their policy rates to the Zero Lower Bound and expanded asset purchase programs. The fact that the policy rates are constrained by their lower bounds 


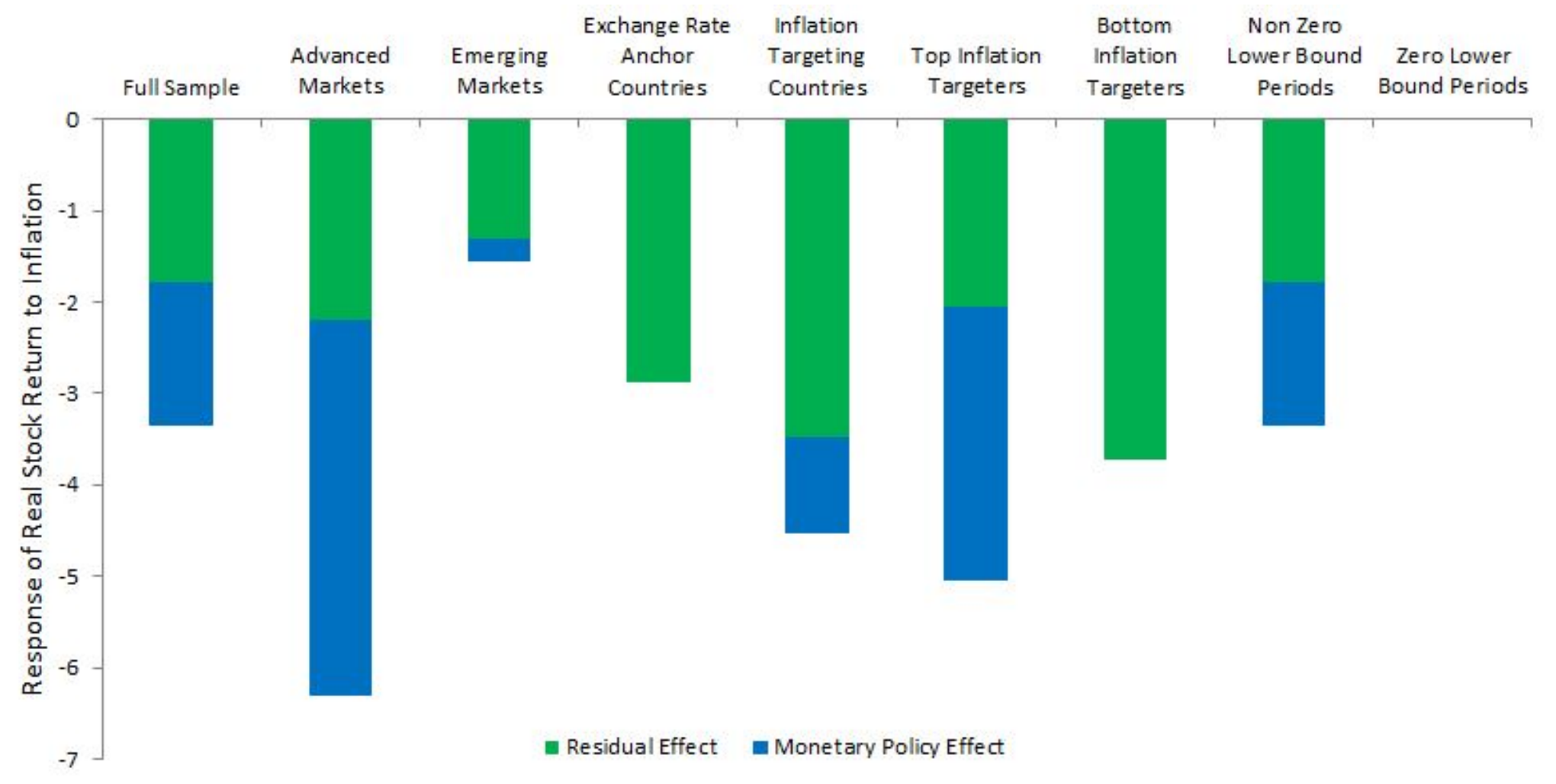

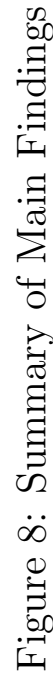

Note: Responsiveness parameters are taken from regression coefficients. Monetary policy cyclicality measures are average values in the sample. 
has resulted in changing patterns of stock return-inflation relations in those countries. This is because central banks can no longer lower policy rates when inflation decreases, but can still raise policy rates as usual when inflation increases. Gourio and Ngo (2016) document a structural break in the response of stock prices to inflation in the United States after 2008. In emerging markets, policymakers should pay special attention to rapid expansions in monetary aggregate, since they can create bubbles in the stock prices and pose a threat to financial stability. Results also imply that central banks that are on market surveillance can do more to shape the market perception of inflation shocks than simply monitor the stock market movements. Central banks' communication to the market is a key to success and the effectiveness of such communications critically depends on central banks' credibility. Specifically, central banks can commit to more countercyclical monetary policy to change the way stock market reacts to inflation. This is particularly relevant, given that a number of emerging markets have evolved from procyclical to countercyclical monetary policy over the last decade (Vegh and Vuletin, 2012).

Results also indicate that practitioners and policymakers in emerging markets should use caution when borrowing the experience from advanced markets. The stock return-inflation relations are distinct in advanced and emerging markets because of differences in the monetary policy cyclicality, the underlying monetary policy framework, central bank's capacity and credibility, and whether policy rate is confined by the Zero Lower Bound. Countries' monetary policy frameworks vary significantly as central banks target different nominal anchors: exchange rate, inflation, monetary aggregate or others. Policy rate cyclicality is the main monetary policy factor that affects the stock return-inflation relation in both advanced and emerging markets, while monetary aggregate growth is also relevant in emerging markets.

There are several possible areas for future research: First, one can further examine the relationship with respect to business cycle conditions. Does the result change during moderate or significant expansions and contractions? Do the amplitude and duration of the business cycles affect the results? What is the interaction between the real business cycles and the financial cycles? Fama and French (1989) argue that the expected returns on stocks and bonds are lower when economic conditions are strong and higher when conditions are weak. Wei (2009) finds that the U.S. nominal equity returns respond more negatively to unexpected inflation during economic contractions 
than expansions. Harding and Pagan (2002) propose an algorithm to locate turning points in the natural logarithm of a series, and their methodology is extensively adopted to define and measure business cycles. Several researchers (Claessens et al., 2011; Drehmann et al., 2012) have identified economic and financial cycles based on the approach.

Second, the study can be extended to several open economy and institutional angles. Many emerging markets are typical small open economies and sensitive to external conditions. It will be interesting to study the role of exchange rate movements and capital flows. Particularly, one can investigate problems that are largely associated with emerging markets. For example, do results differ by crisis types? Are the differences of the stock return-inflation relation among countries due to institutional quality, the stock market openings to foreign investors (Kim and Singal, 2000), or financial liberalization (Kaminsky and Schmukler, 2008)?

Third, this paper confirms that there exists a negative relationship between real stock returns and inflation at the quarterly horizon for many countries. However, it is also useful to examine how stock prices react to inflation at long horizons. Previous research (Boudoukh and Richardson, 1993; Harrison and Zhang, 1999; Schotman and Schweitzer, 2000; Kim and In, 2005) has found a positive relationship between stock returns and inflation over long horizons, and results support the Fisher hypothesis as the horizon increases. 


\section{References}

Adrian, Tobias, Shin, Hyun Song, 2010, "The Changing Nature of Financial Intermediation and the Financial Crisis of 2007-2009", Annual Review of Economics, Vol.2:1-698.

Baker, Malcolm, Stein, Jeremy C. and Wurgler, Jeffrey, 2003, "When Does The Market Matter? Stock Prices And The Investment Of Equity-Dependent Firms," Quarterly Journal of Economics, v118, 969-1006.

Bakshi, G. S. and Chen, Z., 1996, "Inflation, asset prices, and the term structure of interest rates in monetary economics", Review of Financial Studies, 9, 241-275.

Boudoukh, Jacob and Richardson, Matthew, 1993, "Stock Returns and Inflation: A Long-Horizon Perspective", The American Economic Review, Vol. 83, No. 5, pp. 1346-1355.

Boyle, Glenn W. and Peterson, James D., 1995, "Monetary Policy, Aggregate Uncertainty, and the Stock Market", Journal of Money, Credit and Banking, Vol. 27, No. 2, pp. 570-582.

Brandt, M. and Wang, K., 2003, "Time-varying risk aversion and unexpected inflation", Journal of Monetary Economics, 50, 1457-1498.

Campbell, J. and Vuolteenaho, T., 2004, "Inflation Illusion and Stock Prices", American Economic Review, 94, 19-23.

Chen, Nai-Fu, Roll, Richard and Ross, Stephen A., 1986, "Economic Forces and the Stock Market", The Journal of Business, Vol. 59, No. 3, pp. 383-403.

Chen, S., 2007, "Does Monetary Policy Have Asymmetric Effects on Stock Returns?", Journal of Money, Credit and Banking, Vol.39, No. 2-3.

Chinn, Menzie D. and Ito, Hiro, 2006, "What Matters for Financial Development? Capital Controls, Institutions, and Interactions," Journal of Development Economics, Volume 81, Issue 1, Pages 163-192.

Christiano, Lawrence, Ilut, Cosmin, Motto, Roberto, Rostagno, Massimo, 2010. "Monetary policy and stock market booms," Proceedings - Economic Policy Symposium - Jackson Hole, Federal Reserve Bank of Kansas City, pages 85-145. 
Claessens, Stijn , Kose, M. Ayhan and Terrones, Marco E., 2011, "Financial Cycles: What? How? When?" IMF Working Paper 11/76.

Cubeddu et al., 2014, "Emerging Markets in Transition: Growth Prospects and Challenges", IMF Staff Discussion Note 14/06.

Drehmann, Mathias, Borio, Claudio and Tsatsaronis, Kostas, 2012, "Characterising the financial cycle: don't lose sight of the medium term!", BIS Working Papers No 380 .

Driscoll, J., and Kraay, A., 1998, "Consistent covariance matrix estimation with spatially dependent panel data," The Review of Economics and Statistics, 80(4), $549-560$.

Erb, CB, Harvey, CR , Viskanta, TE, 1995, "Inflation and world equity selection", Financial Analysts Journal, Volume 51 Issue 6.

Fama, E., 1981. "Stock returns, real activity, inflation, and money", American Economic Review, 71, 545-65.

Fama, E. and Schwert, W., 1977, "Asset returns and inflation", Journal of Financial Economics, 5, 115-46.

Fama, E. and French, K., 1989, "Business Conditions and Expected Returns on Stocks and Bonds", Journal of Financial Economics, 25, 23-49.

Feldstein, M., 1980, "Inflation and the Stock Market", American Economic Review, 70 (5), 839-847.

Geske, R., Roll, R., 1983, "The fiscal and monetary linkage between stock returns and inflation", the Journal of Finance, Volume 38, Issue 1, Pages 1-33.

Gourio, Francois, Ngo, Phuong, 2016, "Risk Premia at the ZLB: a macroeconomic interpretation", working paper.

Gultekin, NB, 1983, "Stock market returns and inflation: evidence from other countries", Journal of Finance, Vol. 38, No. 1, pp. 49-65.

Harding, D. and Pagan, A., 2002. "Dissecting the cycle: a methodological investigation", Journal of Monetary Economics, 365-381.

Harrison, Paul and Zhang, Harold H., 1999, "An Investigation of the Risk and Return Relation at Long Horizons", Vol. 81, No. 3, Pages 399-408. 
Hoechle, D., 2007, "Robust standard errors for panel regressions with crosssectional dependence," The Stata Journal, 7(3), 281-312.

Ilzetzki, Ethan, Reinhart, Carmen M., Rogoff, Kenneth S., 2017, "Exchange Arrangements Entering the 21st Century: Which Anchor Will Hold?", NBER Working Paper No. 23134.

Kaminsky, Graciela L., Carmen M. Reinhart, and Carlos A. Vegh, 2005, "When It Rains, It Pours: Procyclical Capital Flows and Macroeconomic Policies," in NBER Macroeconomics Annual 2004, Vol.19, ed. by Mark Gertler and Kenneth Rogoff.

Kaminsky, G. and Schmukler, S., 2008, "Short-Run Pain, Long-Run Gain: Financial Liberalization and Stock Market Cycles," Review of Finance, Oxford University Press for European Finance Association, vol. 12(2), pages 253-292.

Katz, Michael, Lustig, Hanno, Nielsen, Lars , 2017, "Are Stocks Real Assets? Sticky Discount Rates in Stock Markets", Review of Financial Studies, (2017) 30 (2): 539-587.

Kaul, G., 1987 "Stock returns and inflation: The role of the monetary sector", Journal of Financial Economics, 18 253-276.

Kim, Sangbae and In, Francis, 2005, "The relationship between stock returns and inflation: new evidence from wavelet analysis", Journal of Empirical Finance, Volume 12, Issue 3, Pages 435-444.

Kim, E. Han, Singal, Vijay, 2000, "Stock Market Openings: Experience of Emerging Economies", Journal of Business, vol. 73, no.1.

Lintner, J., 1975, "Inflation and security returns", Journal of Finance, 30, 259-280.

Marshall, D., 1992, "Inflation and Asset Returns in a Monetary Economy", Journal of Finance, Volume 47, Issue 4, Pages 1315-1342.

Modigliani, F. and Cohn, R. 1979, "Inflation, Rational Valuation, and the Market", Financial Analyst Journal, 35, 24-44.

Outreville, J. F., 2015, "The relationship between relative risk aversion and the level of education: a survey and implications for the demand for life insurance", Journal of Economic Surveys, Volume 29, Issue 1, Pages 97-111.

Pastor, Lubos, and Veronesi, Pietro, 2003, "Stock Prices and IPO Waves", NBER 
Working Paper No. 9858. Schmeling, Maik, 2009, "Investor sentiment and stock returns: Some international evidence ", Journal of Empirical Finance, Volume 16, Issue 3, Pages 394-408.

Schmeling, Maik, and Schrimpf, Andreas, 2011. "Expected inflation, expected stock returns, and money illusion: What can we learn from survey expectations", European Economic Review, 55 702-719.

Schotman, Peter C. and Schweitzer, Mark, 2000, "Horizon sensitivity of the inflation hedge of stocks", Journal of Empirical Finance, Volume 7, Issues 3-4, Pages 301-315.

Sellin, P. , 2001, "'Monetary policy and the stock market: theory and empirical evidence"”, Journal of Economic Surveys, Volume 15, Issue 4, Pages 491-541.

Spyrou, SI, 2004, "Are stocks a good hedge against inflation? Evidence from emerging markets", Applied Economics, 41-48.

Vegh, Carlos A. and Guillermo Vuletin, 2012, "Overcoming the Fear of Free Falling: Monetary Policy Graduation in Emerging Markets," NBER Working Paper No. 18175. Wei, Chao, 2009. "Does the stock market react to unexpected inflation differently across the business cycle", Applied Financial Economics, 1947-1959.

Wu, Jing Cynthia, and Xia, Fan Dora, 2014, "Measuring the Macroeconomic Impact of Monetary Policy at the Zero Lower Bound", NBER Working Paper No. 20117, May 2014. 


\section{Appendix}

\section{Data Description}

Quarterly data from 1980Q1 to 2015Q2. The sample includes 71 economies, covering both advanced and emerging markets.

\section{Country Classification by Income Group}

Advanced Markets (33): Australia, Austria, Belgium, Canada, Cyprus, Czech Republic, Denmark, Estonia, Finland, France, Germany, Greece, Hong Kong SAR, Iceland, Ireland, Israel, Italy, Japan, Luxembourg, Malta, Netherlands, New Zealand, Norway, Portugal, Singapore, Slovak Republic, Slovenia, South Korea, Spain, Sweden, Switzerland, United Kingdom, United States.

Emerging Markets (38): Argentina, Bosnia and Herzegovina, Brazil, Bulgaria, Chile, China, Colombia, Costa Rica, Croatia, Egypt, Hungary, India, Indonesia, Jamaica, Jordan, Kazakhstan, Latvia, Lebanon, Lithuania, Macedonia, Malaysia, Mexico, Morocco, Pakistan, Panama, Peru, Philippines, Poland, Romania, Russia, Serbia, South Africa, Sri Lanka, Thailand, Tunisia, Turkey, Ukraine, Venezuela.

Note: the country classification is based on the International Monetary Fund (IMF)'s World Economic Outlook (WEO).

\section{Panel Data Tests}

Unit root tests are based on Augmented Dickey-Fuller, DF-GLS and Phillips-Perron tests on each variable by country, as well as Im-Pesaran-Shin and Fisher-type tests. Given the panel data is unbalanced in nature, several panel unit root tests are not applicable. Detailed results are available upon request.

Tests for cross-sectional dependence cannot be performed. Given the nature of the dataset, assume cross-section dependence and spatial effects exist.

Wooldridge test for autocorrelation in panel data: we reject the null hypothesis and conclude that the data does have first-order autocorrelation.

Modified Wald test for groupwise heteroscedasticity in fixed effect regression model: we reject the null hypothesis and conclude that the data has heteroscedasticity. 
Table 9: Variable Description

\begin{tabular}{|c|c|c|}
\hline Symbol & Definition & Data source/ Transformation \\
\hline \multicolumn{3}{|c|}{ Original series } \\
\hline stock_index & Stock market index & Bloomberg \\
\hline RGDP & Real GDP & Haver Analytics, IMF IFS and WEO databases. \\
\hline CPI & Consumer price index & IMF INS database \\
\hline inflation_CF_current & Inflation forecasts, current year & Consensus Forecasts \\
\hline inflation_CF_next & Inflation forecasts, next year & Consensus Forecasts \\
\hline IP & Industrial Production & Datastream and IMF IFS databases \\
\hline M2 & M2 (money supply) & Haver Analytics and IMF IFS databases \\
\hline financial_risk & $\begin{array}{l}\text { ICRG financial risk ratings, } \\
\text { from a high of } 50 \text { (least risk) to a low of } 0 \text { (highest risk). }\end{array}$ & International Country Risk Guide (ICRG) database \\
\hline TB3MS & U.S. three-month Treasury Bill: Secondary Market Rate & Board of Governors of the Federal Reserve System \\
\hline VIX & VIX & Bloomberg \\
\hline PR & Central bank's policy rate & Haver Analytics, IMF IFS and GDS databases. \\
\hline WuXiaShadowRate & Wu-Xia shadow federal funds rate & Federal Reserve Bank of Atlanta \\
\hline $\mathrm{MPF}$ & Monetary policy framework & AREAER database, IMF. \\
\hline inflation_target & Inflation targets & Central banks' websites \\
\hline inflation_target_lower & Inflation bands, lower bounds. & Central banks' websites \\
\hline inflation_target_upper & Inflation bands, lower bounds. & Central banks' websites \\
\hline \multicolumn{3}{|c|}{ Derived series } \\
\hline stock_returny & Nominal stock return (log) & $\ln [$ stock_index $(\mathrm{t})]-\ln [$ stock_index $(\mathrm{t}-4)]$ \\
\hline real_stock_index & Real stock market index & stock_index/CPI \\
\hline real_stock_returny & Real stock return (log) & $\ln [$ real_stock_index $(\mathrm{t})]-\ln [$ real_stock_index $(\mathrm{t}-4)]$ \\
\hline inflationy & Inflation (log) & $\ln [\mathrm{CPI}(\mathrm{t})]-\ln [\mathrm{CPI}(\mathrm{t}-4)]$ \\
\hline inflationy_e & Expected inflation & $\begin{array}{l}\text { The measure based on the best forecasting accuracy: } \\
\text { predicted inflation from } \operatorname{AR}(4) \text { model }\end{array}$ \\
\hline inflationy_u & Unexpected inflation & Actual inflation - expected inflation \\
\hline IP_growthy & Industrial production growth & $\ln [\operatorname{IP}(t)]-\ln [\operatorname{IP}(t-4)]$ \\
\hline M2_growthy & Monetary aggregate growth & $\ln [\mathrm{M} 2(\mathrm{t})]-\ln [\mathrm{M} 2(\mathrm{t}-4)]$ \\
\hline financial_risk_change & Improvement in financial risk rating & financial_risk(t) - financial_risk (t-1) \\
\hline MP_correlation_PR & Policy rate cyclicality & Correlation between the cyclical \\
\hline G5_real_stock_returny & Systemic-5 real stock return & $\begin{array}{l}\text { Weighted average of real_stock_returny } \\
\text { in the US, UK, Germany, Japan and China. }\end{array}$ \\
\hline
\end{tabular}




\section{Additional Tests on the Role of Monetary Policy}

In a seminal paper, Bakshi and Chen (1996) offer a tractable asset pricing model in a monetary economy. In the representative-agent economy, the price level, inflation, asset prices, the nominal and real interest rates are determined simultaneously and in relation to each other. The infinitely lived agent chooses consumption, money demand, and portfolio holdings at each point of time to maximize expected life utility. Monetary policy in this economy is such that the resulting money supply follows a stochastic process over time. Based on a Money in the Utility Function Model (MIUF) and an economy with i.i.d. output and money growth processes, the authors show that

$$
\operatorname{cov}_{t}\left(\frac{d q_{t}}{q_{t}}, \frac{d P_{t}}{P_{t}}\right)=\operatorname{cov}_{t}\left(\frac{d y_{t}}{y_{t}}, \frac{d M_{t}}{M_{t}}\right)-\operatorname{var}_{t}\left(\frac{d y_{t}}{y_{t}}\right)
$$

That is, the covariance between the real rate of return on equity and inflation is equal to the covariance between real output growth and nominal money growth, minus the variance of real output growth. In Fama's (1981) proxy hypothesis, money stock is considered as given. This implies a zero covariance between real output and money, and therefore the covariance between real equity return and inflation is negative. In Geske and Roll (1983), monetary policy (money) is countercyclical, thus the covariance between real equity return and inflation is negative as well. Note that the covariance can be positive if the first term on the right hand side of the equation dominates the second term. This is the case in Kaul (1987), where the relationship between stock return and inflation is positive if the monetary authority conducts a procyclical monetary policy.

Boyle and Peterson (1995) extend the theoretical framework of monetary policy and stock returns to address the question of whether monetary policy matters, as different from the question whether money matters. They achieve this by assuming that the monetary policy targets the growth rate of money. ${ }^{19}$ In a Cash-in-Advance (CIA) Model, the simplified reaction function of the monetary authority is given by:

$$
\mu_{t}=k \lambda_{t}^{\epsilon}
$$

\footnotetext{
${ }^{19}$ In the original version of the reaction function of Boyle and Peterson (1995), there is an additional disturbance term $\theta$ which represents imperfect implementation of monetary policy.
} 
where $k>0$ is a constant and $\epsilon$ is the elasticity of the monetary response to an output shock. Under the assumption that $\lambda_{t}$ is i.i.d. and constant risk aversion preferences, a central finding in Boyle and Peterson (1995) is the following relation:

$$
\operatorname{cov}_{t}\left(\ln q_{t}^{*}, \ln \Pi_{t}\right)=\operatorname{cov}\left(\lambda_{t},(\epsilon-1) \ln \lambda_{t}\right)=(\epsilon-1) \operatorname{var}\left(\lambda_{t}\right)
$$

where $q_{t}^{*}=q_{t} / q_{t-1}=y_{t} / y_{t-1}, \Pi_{t}=P_{t} / P_{t-1}$. Therefore, equity returns are negatively correlated with inflation when monetary policy is countercyclical $(\epsilon<0)$ or weakly procyclical $(0<\epsilon<1)$, and the correlation is positive when monetary policy is strongly procyclical $(\epsilon>1)$.

Linear Regression Model:

$$
\operatorname{cov}_{i}(r, p i)=\alpha+\beta_{1} \operatorname{cov}_{i}(y, m)+\beta_{2} \operatorname{var}_{i}(y)+\epsilon_{i}
$$

Joint test: $\alpha=0, \beta_{1}=1, \beta_{2}=-1$.

Table 10: Summary Statistics to Test the Bakshi-Chen Hypothesis

\begin{tabular}{cccccc}
\hline Variable & Observation & Mean & Std. dev. & Min & Max \\
\hline $\operatorname{Cov}(\mathrm{r}, \mathrm{pi})$ & 63 & 0.0179 & 0.1497 & -0.0176 & 1.186 \\
$\operatorname{Cov}(\mathrm{y}, \mathrm{m})$ & 63 & 0.0017 & 0.0030 & -0.0023 & 0.015 \\
$\operatorname{Var}(\mathrm{y})$ & 63 & 0.0015 & 0.0016 & 0.00003 & 0.0075 \\
\hline
\end{tabular}

To test whether the relationship between stock returns and inflation is partially driven by monetary policy cyclicality, I test Equation (4), which is a simple relationship on two covariance terms and one variance term. There are 63 countries included in the test, with different sample periods, depending on data availability. The cross-sectional regression utilizes a single observation from each country. Summary statistics show that the covariance between real stock return and inflation is much larger in terms of magnitude compared to the covariance between real output and monetary aggregate, and the variance of real output. Results from Ordinary Least Squares indicate that the covariance between the real rate of return on equity and inflation is significantly positively correlated with the covariance between real output growth and nominal money growth and negatively correlated with the variance of real output growth. The signs of the estimated coefficients are pointing to the correct di- 
Table 11: Test the Bakshi-Chen Monetary Policy Hypothesis

\begin{tabular}{ccccccc}
\hline Dependent variable: cov(r, pi) & $(1)$ & $(2)$ & $(3)$ & $(4)$ & $(5)$ & $(6)$ \\
\hline $\operatorname{cov}(\mathrm{y}, \mathrm{m})$ & $48.33^{* *}$ & $48.27^{* *}$ & -0.134 & 0.00199 & $50.65^{* *}$ & $51.39^{* *}$ \\
& $(20.77)$ & $(21.34)$ & $(1.028)$ & $(0.904)$ & $(21.29)$ & $(21.51)$ \\
$\operatorname{var}(\mathrm{y})$ & $-58.47^{* *}$ & $-50.33^{* *}$ & -0.659 & $-0.974^{* *}$ & $-62.55^{* *}$ & $-57.54^{* *}$ \\
& $(26.21)$ & $(23.12)$ & $(0.682)$ & $(0.446)$ & $(27.79)$ & $(25.85)$ \\
Constant & $0.0254^{*}$ & & -0.000381 & & 0.0228 & \\
& $(0.0148)$ & & $(0.000376)$ & & $(0.0241)$ & \\
Estimation method & & & & & & \\
Sample & OLS & OLS & OLS & OLS & OLS & OLS \\
Observations & 63 & full & AM & AM & EM & EM \\
R-squared & 0.592 & 0.583 & 0.115 & 0.314 & 0.610 & 0.617 \\
\hline
\end{tabular}

Note: Robust standard errors in parentheses. ${ }^{* * *} \mathrm{p}<0.01 ;{ }^{* *} \mathrm{p}<0.05 ;{ }^{*} \mathrm{p}<0.1$.

rection, however, the relation suggested that the theory does not hold precisely, since the estimated coefficients are much bigger than 1 and -1, implied by Equation (4). The estimated coefficients for advanced markets are closer to theoretical predictions, but the estimated coefficients for emerging markets are far beyond theoretical predictions. The unrealistic assumption of i.i.d. output and money growth processes makes it difficult to reconcile the discrepancy between theoretical predictions and empirical findings. 
Table 12: Robustness Check: Use Actual Inflation and Test the Stock Return-Inflation Relation is Less Negative in EMs

\begin{tabular}{|c|c|c|c|c|c|c|c|c|}
\hline Dependent variable: real stock return & (1) & $(2)$ & (3) & (4) & $(5)$ & (6) & (7) & (8) \\
\hline Inflation & $\begin{array}{c}-1.785^{* * *} \\
(0.313)\end{array}$ & $\begin{array}{c}-2.200^{* *} \\
(0.963)\end{array}$ & $\begin{array}{c}-1.312^{* * *} \\
(0.274)\end{array}$ & $\begin{array}{c}-4.553^{* * *} \\
(0.994)\end{array}$ & $\begin{array}{c}-0.807^{* * *} \\
(0.250)\end{array}$ & $\begin{array}{l}-2.391 \\
(1.540)\end{array}$ & $\begin{array}{c}-0.863^{* * *} \\
(0.260)\end{array}$ & $\begin{array}{c}-3.637^{* * *} \\
(1.268)\end{array}$ \\
\hline Inflation $\times$ EM dummy & & & & $\begin{array}{c}3.202^{* * *} \\
(0.945)\end{array}$ & & & & $\begin{array}{c}2.846^{* *} \\
(1.201)\end{array}$ \\
\hline Inflation $\times$ policy rate cyclicality & $\begin{array}{c}-4.851^{* * *} \\
(0.878)\end{array}$ & $\begin{array}{c}-7.553^{* * *} \\
(1.750)\end{array}$ & $\begin{array}{c}-2.172^{* *} \\
(0.970)\end{array}$ & $\begin{array}{c}-2.869^{* * *} \\
(0.714)\end{array}$ & & & & \\
\hline Inflation $\times$ countercyclical policy dummy & & & & & $\begin{array}{c}-3.978^{* * *} \\
(0.677)\end{array}$ & $\begin{array}{c}-3.503^{* *} \\
(1.737)\end{array}$ & $\begin{array}{c}-2.255^{* * *} \\
(0.676)\end{array}$ & $\begin{array}{c}-2.416^{* * *} \\
(0.649)\end{array}$ \\
\hline Industrial production growth rate & $\begin{array}{c}1.218^{* * *} \\
(0.169)\end{array}$ & $\begin{array}{c}0.973^{* * *} \\
(0.182)\end{array}$ & $\begin{array}{c}1.434^{* * *} \\
(0.227)\end{array}$ & $\begin{array}{c}1.240^{* * *} \\
(0.174)\end{array}$ & $\begin{array}{c}1.223^{* * *} \\
(0.162)\end{array}$ & $\begin{array}{c}0.926^{* * *} \\
(0.186)\end{array}$ & $\begin{array}{c}1.446^{* * *} \\
(0.218)\end{array}$ & $\begin{array}{c}1.239 * * * \\
(0.169)\end{array}$ \\
\hline M2 growth rate & $\begin{array}{c}0.410^{* *} \\
(0.195)\end{array}$ & $\begin{array}{c}0.0197 \\
(0.279)\end{array}$ & $\begin{array}{c}0.634^{* * *} \\
(0.172)\end{array}$ & $\begin{array}{c}0.404^{* *} \\
(0.194)\end{array}$ & $\begin{array}{c}0.392^{* *} \\
(0.196)\end{array}$ & $\begin{array}{c}0.00262 \\
(0.293)\end{array}$ & $\begin{array}{c}0.621^{* * *} \\
(0.169)\end{array}$ & $\begin{array}{c}0.394^{* *} \\
(0.195)\end{array}$ \\
\hline Improvement in financial risk rating & $\begin{array}{c}0.0121^{* *} \\
(0.00498)\end{array}$ & $\begin{array}{c}0.00116 \\
(0.00569)\end{array}$ & $\begin{array}{c}0.0212^{* * *} \\
(0.00520)\end{array}$ & $\begin{array}{c}0.0118^{* *} \\
(0.00494)\end{array}$ & $\begin{array}{l}0.0117^{* *} \\
(0.00492)\end{array}$ & $\begin{array}{c}0.000963 \\
(0.00587)\end{array}$ & $\begin{array}{c}0.0209^{* * *} \\
(0.00509)\end{array}$ & $\begin{array}{l}0.0116^{* *} \\
(0.00492)\end{array}$ \\
\hline U.S 3-month Treasury bill yield rate & $\begin{array}{l}0.00880 \\
(0.0104)\end{array}$ & $\begin{array}{l}0.0194^{*} \\
(0.0100)\end{array}$ & $\begin{array}{l}-0.00203 \\
(0.0131)\end{array}$ & $\begin{array}{c}0.0104 \\
(0.0103)\end{array}$ & $\begin{array}{l}0.00968 \\
(0.0101)\end{array}$ & $\begin{array}{l}0.0200^{*} \\
(0.0104)\end{array}$ & $\begin{array}{r}-0.00150 \\
(0.0128)\end{array}$ & $\begin{array}{c}0.0106 \\
(0.0102)\end{array}$ \\
\hline VIX & $\begin{array}{c}-0.0164^{* * *} \\
(0.00291)\end{array}$ & $\begin{array}{c}-0.0168^{* * *} \\
(0.00267)\end{array}$ & $\begin{array}{c}-0.0154^{* * *} \\
(0.00344)\end{array}$ & $\begin{array}{c}-0.0161^{* * *} \\
(0.00285)\end{array}$ & $\begin{array}{c}-0.0162^{* * *} \\
(0.00291)\end{array}$ & $\begin{array}{c}-0.0169^{* * *} * \\
(0.00272)\end{array}$ & $\begin{array}{c}-0.0151^{* * *} \\
(0.00343)\end{array}$ & $\begin{array}{c}-0.0161^{* * *} \\
(0.00286)\end{array}$ \\
\hline Constant & $\begin{array}{c}0.379^{* * *} \\
(0.0745)\end{array}$ & $\begin{array}{c}0.432^{* * *} \\
(0.0691)\end{array}$ & $\begin{array}{c}0.310^{* * *} \\
(0.0812)\end{array}$ & $\begin{array}{c}0.380^{* * *} \\
(0.0732)\end{array}$ & $\begin{array}{c}0.377^{* * *} \\
(0.0733)\end{array}$ & $\begin{array}{c}0.424^{* * *} \\
(0.0707)\end{array}$ & $\begin{array}{c}0.310^{* * *} \\
(0.0794)\end{array}$ & $\begin{array}{c}0.378^{* * *} \\
(0.0730)\end{array}$ \\
\hline Sample & full & $\mathrm{AM}$ & EM & full & full & $\mathrm{AM}$ & $\mathrm{EM}$ & full \\
\hline Observations & 3,498 & 1,944 & 1,554 & 3,498 & 3,498 & 1,944 & 1,554 & 3,498 \\
\hline R-squared & 0.3992 & 0.455 & 0.3928 & 0.4078 & 0.4019 & 0.4468 & 0.3958 & 0.4076 \\
\hline Number of countries & 55 & 27 & 28 & 55 & 55 & 27 & 28 & 55 \\
\hline
\end{tabular}


Table 13: Robustness Check: Drop the Observations when Countries Adopted the Euro

\begin{tabular}{|c|c|c|c|c|c|c|}
\hline Dependent variable: real stock return & $(1)$ & $(2)$ & $(3)$ & $(4)$ & $(5)$ & $(6)$ \\
\hline Expected inflation & $\begin{array}{c}-1.834^{* * *} \\
(0.381)\end{array}$ & $\begin{array}{c}-2.525^{* *} \\
(1.012)\end{array}$ & $\begin{array}{c}-1.341^{* * *} \\
(0.301)\end{array}$ & $\begin{array}{c}-0.791^{* * *} \\
(0.289)\end{array}$ & $\begin{array}{c}-3.120^{* *} \\
(1.400)\end{array}$ & $\begin{array}{c}-0.865^{* * *} \\
(0.292)\end{array}$ \\
\hline Unexpected inflation & $\begin{array}{c}-1.627^{* * *} \\
(0.533)\end{array}$ & $\begin{array}{l}-1.017 \\
(1.985)\end{array}$ & $\begin{array}{c}-1.224^{* * *} \\
(0.463)\end{array}$ & $\begin{array}{l}-0.906 \\
(0.596)\end{array}$ & $\begin{array}{l}-3.264^{*} \\
(1.807)\end{array}$ & $\begin{array}{c}-0.864^{*} \\
(0.517)\end{array}$ \\
\hline Expected inflation $\times$ policy rate cyclicality & $\begin{array}{c}-5.205^{* * *} \\
(1.093)\end{array}$ & $\begin{array}{c}-10.69^{* * *} \\
(3.948)\end{array}$ & $\begin{array}{c}-2.362^{* *} \\
(1.052)\end{array}$ & & & \\
\hline Unexpected inflation $\times$ policy rate cyclicality & $\begin{array}{l}-2.746 \\
(1.823)\end{array}$ & $\begin{array}{c}-7.238^{*} \\
(4.196)\end{array}$ & $\begin{array}{l}-0.951 \\
(1.406)\end{array}$ & & & \\
\hline Expected inflation $\times$ countercyclical policy dummy & & & & $\begin{array}{c}-4.372^{* * *} \\
(0.718)\end{array}$ & $\begin{array}{c}-4.354^{* *} \\
(1.748)\end{array}$ & $\begin{array}{c}-2.311^{* * *} \\
(0.735)\end{array}$ \\
\hline Unexpected inflation $\times$ countercyclical policy dummy & & & & $\begin{array}{c}-2.885^{* *} \\
(1.142)\end{array}$ & $\begin{array}{c}0.256 \\
(1.870)\end{array}$ & $\begin{array}{c}-2.241^{* *} \\
(0.949)\end{array}$ \\
\hline Industrial production growth rate & $\begin{array}{c}1.227^{* * *} \\
(0.186)\end{array}$ & $\begin{array}{c}0.856^{* * *} \\
(0.229)\end{array}$ & $\begin{array}{c}1.428^{* * *} \\
(0.229)\end{array}$ & $\begin{array}{c}1.236^{* * *} \\
(0.178)\end{array}$ & $\begin{array}{c}0.755^{* * *} \\
(0.241)\end{array}$ & $\begin{array}{c}1.444^{* * *} \\
(0.221)\end{array}$ \\
\hline M2 growth rate & $\begin{array}{l}0.388^{*} \\
(0.207)\end{array}$ & $\begin{array}{l}-0.334 \\
(0.335)\end{array}$ & $\begin{array}{c}0.638^{* * *} \\
(0.173)\end{array}$ & $\begin{array}{l}0.371^{*} \\
(0.206)\end{array}$ & $\begin{array}{l}-0.349 \\
(0.349)\end{array}$ & $\begin{array}{c}0.628^{* * *} \\
(0.170)\end{array}$ \\
\hline Improvement in financial risk rating & $\begin{array}{c}0.0160 * * * \\
(0.00526)\end{array}$ & $\begin{array}{c}0.00438 \\
(0.00560)\end{array}$ & $\begin{array}{c}0.0210^{* * *} \\
(0.00538)\end{array}$ & $\begin{array}{c}0.0156^{* * *} \\
(0.00517)\end{array}$ & $\begin{array}{c}0.00472 \\
(0.00593)\end{array}$ & $\begin{array}{c}0.0208^{* * *} \\
(0.00528)\end{array}$ \\
\hline U.S 3-month Treasury bill yield rate & $\begin{array}{l}0.00502 \\
(0.0106)\end{array}$ & $\begin{array}{c}0.0150 \\
(0.0101)\end{array}$ & $\begin{array}{l}-0.00203 \\
(0.0131)\end{array}$ & $\begin{array}{l}0.00593 \\
(0.0103)\end{array}$ & $\begin{array}{c}0.0157 \\
(0.0106)\end{array}$ & $\begin{array}{c}-0.00168 \\
(0.0128)\end{array}$ \\
\hline VIX & $\begin{array}{c}-0.0152^{* * *} \\
(0.00294)\end{array}$ & $\begin{array}{c}-0.0140 * * * \\
(0.00227)\end{array}$ & $\begin{array}{c}-0.0153^{* * *} \\
(0.00345)\end{array}$ & $\begin{array}{c}-0.0149^{* * *} \\
(0.00293)\end{array}$ & $\begin{array}{c}-0.0141^{* * *} \\
(0.00233)\end{array}$ & $\begin{array}{c}-0.0151^{* * *} \\
(0.00345)\end{array}$ \\
\hline Constant & $\begin{array}{c}0.371^{* * *} \\
(0.0802)\end{array}$ & $\begin{array}{c}0.453^{* * *} \\
(0.0672)\end{array}$ & $\begin{array}{l}0.310^{* * *} \\
(0.0810)\end{array}$ & $\begin{array}{c}0.371^{* * *} \\
(0.0775)\end{array}$ & $\begin{array}{c}0.455^{* * *} \\
(0.0701)\end{array}$ & $\begin{array}{l}0.311^{* * *} \\
(0.0793)\end{array}$ \\
\hline Sample & full & $\mathrm{AM}$ & EM & full & $\mathrm{AM}$ & EM \\
\hline Observations & 2,701 & 1,149 & 1,552 & 2,701 & 1,149 & 1,552 \\
\hline R-squared & 0.3774 & 0.4564 & 0.3935 & 0.3825 & 0.443 & 0.3963 \\
\hline Number of countries & 45 & 17 & 28 & 45 & 17 & 28 \\
\hline
\end{tabular}


Table 14: Robustness Check: Drop Inflation Above 100\%

\begin{tabular}{|c|c|c|c|c|c|c|}
\hline Dependent variable: real stock return & $(1)$ & $(2)$ & $(3)$ & $(4)$ & $(5)$ & $(6)$ \\
\hline Expected inflation & $\begin{array}{c}-1.871^{* * *} \\
(0.344)\end{array}$ & $\begin{array}{c}-2.561^{* *} \\
(0.990)\end{array}$ & $\begin{array}{c}-1.355^{* * *} \\
(0.305)\end{array}$ & $\begin{array}{c}-0.929^{* * *} \\
(0.273)\end{array}$ & $\begin{array}{l}-2.498 \\
(1.558)\end{array}$ & $\begin{array}{c}-1.008^{* * *} \\
(0.281)\end{array}$ \\
\hline Unexpected inflation & $\begin{array}{c}-1.347^{* *} \\
(0.573)\end{array}$ & $\begin{array}{l}-2.399 \\
(1.657)\end{array}$ & $\begin{array}{c}-1.305^{* * *} \\
(0.474)\end{array}$ & $\begin{array}{c}-1.162^{*} \\
(0.674)\end{array}$ & $\begin{array}{l}-3.096 \\
(2.127)\end{array}$ & $\begin{array}{l}-1.074 * \\
(0.554)\end{array}$ \\
\hline Expected inflation $\times$ policy rate cyclicality & $\begin{array}{c}-5.541^{* * *} \\
(0.927)\end{array}$ & $\begin{array}{c}-8.284^{* * *} \\
(1.704)\end{array}$ & $\begin{array}{l}-1.869^{*} \\
(1.114)\end{array}$ & & & \\
\hline Unexpected inflation $\times$ policy rate cyclicality & $\begin{array}{l}-0.379 \\
(1.445)\end{array}$ & $\begin{array}{l}2.390 \\
(2.687)\end{array}$ & $\begin{array}{l}-0.305 \\
(1.425)\end{array}$ & & & \\
\hline Expected inflation $\times$ countercyclical policy dummy & & & & $\begin{array}{c}-4.327^{* * *} \\
(0.679)\end{array}$ & $\begin{array}{c}-4.387^{* *} \\
(1.768)\end{array}$ & $\begin{array}{c}-2.137^{* * *} \\
(0.726)\end{array}$ \\
\hline Unexpected inflation $\times$ countercyclical policy dummy & & & & $\begin{array}{l}-1.134 \\
(0.871)\end{array}$ & $\begin{array}{c}2.615 \\
(2.063)\end{array}$ & $\begin{array}{c}-1.983^{* *} \\
(0.950)\end{array}$ \\
\hline Industrial production growth rate & $\begin{array}{c}1.180^{* * *} \\
(0.165)\end{array}$ & $\begin{array}{c}0.872^{* * *} \\
(0.185)\end{array}$ & $\begin{array}{c}1.435^{* * *} \\
(0.230)\end{array}$ & $\begin{array}{c}1.189^{* * *} \\
(0.159)\end{array}$ & $\begin{array}{c}0.818^{* * *} \\
(0.192)\end{array}$ & $\begin{array}{c}1.452^{* * *} \\
(0.222)\end{array}$ \\
\hline M2 growth rate & $\begin{array}{c}0.408^{* *} \\
(0.191)\end{array}$ & $\begin{array}{l}0.0307 \\
(0.273)\end{array}$ & $\begin{array}{c}0.633^{* * *} \\
(0.176)\end{array}$ & $\begin{array}{c}0.406^{* *} \\
(0.192)\end{array}$ & $\begin{array}{c}0.0168 \\
(0.285)\end{array}$ & $\begin{array}{c}0.632^{* * *} \\
(0.173)\end{array}$ \\
\hline Improvement in financial risk rating & $\begin{array}{l}0.0118^{* *} \\
(0.00476)\end{array}$ & $\begin{array}{c}0.00141 \\
(0.00539)\end{array}$ & $\begin{array}{c}0.0208^{* * *} \\
(0.00534)\end{array}$ & $\begin{array}{c}0.0118^{* *} \\
(0.00477)\end{array}$ & $\begin{array}{c}0.00161 \\
(0.00547)\end{array}$ & $\begin{array}{c}0.0209 * * * \\
(0.00522)\end{array}$ \\
\hline U.S 3-month Treasury bill yield rate & $\begin{array}{l}0.00891 \\
(0.0102)\end{array}$ & $\begin{array}{c}0.0190^{* *} \\
(0.00953)\end{array}$ & $\begin{array}{c}-0.00194 \\
(0.0132)\end{array}$ & $\begin{array}{c}0.00971 \\
(0.00994)\end{array}$ & $\begin{array}{c}0.0198^{* *} \\
(0.00994)\end{array}$ & $\begin{array}{c}-0.00139 \\
(0.0128)\end{array}$ \\
\hline VIX & $\begin{array}{c}-0.0161^{* * *} \\
(0.00279)\end{array}$ & $\begin{array}{c}-0.0163^{* * *} \\
(0.00240)\end{array}$ & $\begin{array}{c}-0.0153^{* * *} \\
(0.00345)\end{array}$ & $\begin{array}{c}-0.0159^{* * *} \\
(0.00280)\end{array}$ & $\begin{array}{c}-0.0163^{* * *} \\
(0.00245)\end{array}$ & $\begin{array}{c}-0.0150^{* * *} \\
(0.00340)\end{array}$ \\
\hline Constant & $\begin{array}{c}0.383^{* * *} \\
(0.0728)\end{array}$ & $\begin{array}{c}0.442^{* * *} \\
(0.0653)\end{array}$ & $\begin{array}{c}0.311^{* * *} \\
(0.0814)\end{array}$ & $\begin{array}{c}0.383^{* * *} \\
(0.0717)\end{array}$ & $\begin{array}{c}0.438^{* * *} \\
(0.0675)\end{array}$ & $\begin{array}{c}0.313^{* * *} \\
(0.0793)\end{array}$ \\
\hline Sample & full & $\mathrm{AM}$ & EM & full & $\mathrm{AM}$ & $\mathrm{EM}$ \\
\hline Observations & 3,496 & 1,944 & 1,552 & 3,496 & 1,944 & 1,552 \\
\hline R-squared & 0.4043 & 0.4704 & 0.3949 & 0.4072 & 0.4633 & 0.3994 \\
\hline Number of countries & 55 & 27 & 28 & 55 & 27 & 28 \\
\hline
\end{tabular}


Table 15: Robustness Check: Re-run Regressions using Consensus Forecasts Data

\begin{tabular}{|c|c|c|c|c|c|c|}
\hline Dependent variable: real stock return & $(1)$ & $(2)$ & $(3)$ & $(4)$ & $(5)$ & $(6)$ \\
\hline Expected inflation (Consensus Forecasts, current year) & $\begin{array}{c}-1.314^{* *} \\
(0.573)\end{array}$ & $\begin{array}{l}-1.000 \\
(1.343)\end{array}$ & $\begin{array}{l}-0.814 \\
(0.544)\end{array}$ & & & \\
\hline Unexpected inflation (Consensus Forecasts, current year) & $\begin{array}{c}-1.937^{* * *} \\
(0.344)\end{array}$ & $\begin{array}{c}-3.877^{* * *} \\
(1.267)\end{array}$ & $\begin{array}{c}-1.802^{* * *} \\
(0.434)\end{array}$ & & & \\
\hline Unexpected inflation (Consensus Forecasts, current year) $\times$ policy rate cyclicality & $\begin{array}{c}-4.571^{* * *} \\
(1.149)\end{array}$ & $\begin{array}{l}-1.443 \\
(2.550)\end{array}$ & $\begin{array}{c}-3.628^{* *} \\
(1.547)\end{array}$ & & & \\
\hline Expected inflation (Consensus Forecasts, next year) & & & & $\begin{array}{c}-1.759^{* * *} \\
(0.493)\end{array}$ & $\begin{array}{c}-1.894^{*} \\
(0.957)\end{array}$ & $\begin{array}{c}-1.245^{* * *} \\
(0.444)\end{array}$ \\
\hline Expected inflation (Consensus Forecasts, next year) $\times$ policy rate cyclicality & & & & $\begin{array}{c}-4.173^{* * *} \\
(1.187)\end{array}$ & $\begin{array}{c}-7.033^{* * *} \\
(1.525)\end{array}$ & $\begin{array}{c}-1.960^{*} \\
(1.140)\end{array}$ \\
\hline Unexpected inflation (Consensus Forecasts, next year) $\times$ policy rate cyclicality & & & & $\begin{array}{l}-3.000 \\
(2.096)\end{array}$ & $\begin{array}{c}4.423 \\
(3.278)\end{array}$ & $\begin{array}{c}-3.655^{*} \\
(2.155)\end{array}$ \\
\hline Industrial production growth rate & $\begin{array}{c}1.275^{* * *} \\
(0.165)\end{array}$ & $\begin{array}{c}1.100^{* * *} \\
(0.158)\end{array}$ & $\begin{array}{c}1.406^{* * *} \\
(0.242)\end{array}$ & $\begin{array}{c}1.271^{* * *} \\
(0.165)\end{array}$ & $\begin{array}{c}1.086^{* * *} \\
(0.151)\end{array}$ & $\begin{array}{c}1.419^{* * *} \\
(0.245)\end{array}$ \\
\hline M2 growth rate & $\begin{array}{c}0.533^{* * *} \\
(0.154)\end{array}$ & $\begin{array}{c}0.443^{* *} \\
(0.174)\end{array}$ & $\begin{array}{c}0.563^{* * *} \\
(0.190)\end{array}$ & $\begin{array}{c}0.551^{* * * *} \\
(0.149)\end{array}$ & $\begin{array}{c}0.475^{* * *} \\
(0.169)\end{array}$ & $\begin{array}{c}0.574^{* * *} \\
(0.185)\end{array}$ \\
\hline U.S 3-month Treasury bill yield rate & $\begin{array}{l}0.00280 \\
(0.0101)\end{array}$ & $\begin{array}{c}0.0103 \\
(0.00920)\end{array}$ & $\begin{array}{r}-0.00575 \\
(0.0140)\end{array}$ & $\begin{array}{c}0.00394 \\
(0.00998)\end{array}$ & $\begin{array}{c}0.0106 \\
(0.00867)\end{array}$ & $\begin{array}{c}-0.00502 \\
(0.0137)\end{array}$ \\
\hline VIX & $\begin{array}{c}-0.0160^{* * * *} \\
(0.00281)\end{array}$ & $\begin{array}{c}-0.0162^{* * *} \\
(0.00252)\end{array}$ & $\begin{array}{c}-0.0158^{* * *} \\
(0.00355)\end{array}$ & $\begin{array}{c}-0.0160 * * * \\
(0.00278)\end{array}$ & $\begin{array}{c}-0.0162^{* * * *} \\
(0.00251)\end{array}$ & $\begin{array}{c}-0.0159^{* * *} * \\
(0.00351)\end{array}$ \\
\hline Constant & $\begin{array}{c}0.334^{* * *} \\
(0.0666)\end{array}$ & $\begin{array}{c}0.376^{* * *} \\
(0.0555)\end{array}$ & $\begin{array}{c}0.302^{* * *} \\
(0.0871)\end{array}$ & $\begin{array}{c}0.358^{* * *} * \\
(0.0723)\end{array}$ & $\begin{array}{c}0.389^{* * *} \\
(0.0607)\end{array}$ & $\begin{array}{c}0.323^{* * *} \\
(0.0922)\end{array}$ \\
\hline Sample & full & $\mathrm{AM}$ & EM & full & $\mathrm{AM}$ & EM \\
\hline Observations & 3,050 & 1,768 & 1,282 & 3,050 & 1,768 & 1,282 \\
\hline R-squared & 0.4177 & 0.4545 & 0.4051 & 0.4171 & 0.4595 & 0.4041 \\
\hline Number of countries & 51 & 25 & 26 & 51 & 25 & 26 \\
\hline
\end{tabular}


Table 16: Robustness Check: Add the Measure of Global Stock Market Factor

\begin{tabular}{|c|c|c|c|c|c|c|}
\hline Dependent variable: real stock return & $(1)$ & $(2)$ & $(3)$ & $(4)$ & $(5)$ & $(6)$ \\
\hline Expected inflation & $\begin{array}{c}-1.554^{* * *} \\
(0.302)\end{array}$ & $\begin{array}{c}-2.336^{* *} \\
(0.986)\end{array}$ & $\begin{array}{c}-1.250^{* * *} \\
(0.289)\end{array}$ & $\begin{array}{c}-0.857^{* * *} \\
(0.246)\end{array}$ & $\begin{array}{l}-1.445 \\
(0.975)\end{array}$ & $\begin{array}{c}-0.927^{* * *} \\
(0.257)\end{array}$ \\
\hline Unexpected inflation & $\begin{array}{c}-1.468^{* *} \\
(0.590)\end{array}$ & $\begin{array}{l}-2.577 \\
(1.718)\end{array}$ & $\begin{array}{c}-1.271^{* *} \\
(0.560)\end{array}$ & $\begin{array}{l}-1.015 \\
(0.662)\end{array}$ & $\begin{array}{l}-2.515 \\
(1.657)\end{array}$ & $\begin{array}{l}-0.936 \\
(0.593)\end{array}$ \\
\hline Expected inflation $\times$ policy rate cyclicality & $\begin{array}{c}-3.585^{* * *} \\
(0.777)\end{array}$ & $\begin{array}{c}-4.820^{* *} \\
(2.181)\end{array}$ & $\begin{array}{l}-1.699 \\
(1.128)\end{array}$ & & & \\
\hline Unexpected inflation $\times$ policy rate cyclicality & $\begin{array}{l}-1.389 \\
(1.625)\end{array}$ & $\begin{array}{c}0.665 \\
(2.492)\end{array}$ & $\begin{array}{l}-0.909 \\
(1.663)\end{array}$ & & & \\
\hline Expected inflation $\times$ countercyclical policy dummy & & & & $\begin{array}{c}-2.831^{* * *} \\
(0.684)\end{array}$ & $\begin{array}{c}-3.446^{* *} \\
(1.357)\end{array}$ & $\begin{array}{l}-1.298 \\
(0.928)\end{array}$ \\
\hline Unexpected inflation $\times$ countercyclical policy dummy & & & & $\begin{array}{c}-1.794 \\
(1.092)\end{array}$ & $\begin{array}{c}0.770 \\
(1.754)\end{array}$ & $\begin{array}{c}-1.905^{*} \\
(1.112)\end{array}$ \\
\hline Industrial production growth rate & $\begin{array}{c}0.943^{* * *} \\
(0.135)\end{array}$ & $\begin{array}{c}0.604^{* * *} \\
(0.161)\end{array}$ & $\begin{array}{c}1.172^{* * *} \\
(0.165)\end{array}$ & $\begin{array}{c}0.950^{* * *} \\
(0.132)\end{array}$ & $\begin{array}{c}0.562^{* * *} \\
(0.174)\end{array}$ & $\begin{array}{c}1.189^{* * *} \\
(0.164)\end{array}$ \\
\hline M2 growth rate & $\begin{array}{c}0.507^{* * *} \\
(0.142)\end{array}$ & $\begin{array}{c}0.00456 \\
(0.227)\end{array}$ & $\begin{array}{c}0.771^{* * *} \\
(0.126)\end{array}$ & $\begin{array}{c}0.495^{* * *} \\
(0.142)\end{array}$ & $\begin{array}{c}-0.00453 \\
(0.235)\end{array}$ & $\begin{array}{c}0.762^{* * *} \\
(0.124)\end{array}$ \\
\hline Improvement in financial risk rating & $\begin{array}{c}0.0156^{* * *} \\
(0.00409)\end{array}$ & $\begin{array}{c}0.00903 \\
(0.00617)\end{array}$ & $\begin{array}{c}0.0195^{* * *} \\
(0.00465)\end{array}$ & $\begin{array}{c}0.0155^{* * *} \\
(0.00417)\end{array}$ & $\begin{array}{c}0.00937 \\
(0.00624)\end{array}$ & $\begin{array}{c}0.0195^{* * *} \\
(0.00464)\end{array}$ \\
\hline U.S 3-month Treasury bill yield rate & $\begin{array}{c}0.00419 \\
(0.00794)\end{array}$ & $\begin{array}{l}0.0180^{* *} \\
(0.00782)\end{array}$ & $\begin{array}{c}-0.00754 \\
(0.0106)\end{array}$ & $\begin{array}{c}0.00480 \\
(0.00775)\end{array}$ & $\begin{array}{l}0.0186^{* *} \\
(0.00806)\end{array}$ & $\begin{array}{c}-0.00746 \\
(0.0105)\end{array}$ \\
\hline VIX & $\begin{array}{l}-0.00455 \\
(0.00303)\end{array}$ & $\begin{array}{c}-0.00605^{* *} \\
(0.00269)\end{array}$ & $\begin{array}{l}-0.00337 \\
(0.00372)\end{array}$ & $\begin{array}{l}-0.00454 \\
(0.00304)\end{array}$ & $\begin{array}{c}-0.00595^{* *} \\
(0.00264)\end{array}$ & $\begin{array}{c}-0.00343 \\
(0.00374)\end{array}$ \\
\hline Systemic-5 real stock return & $\begin{array}{c}0.784^{* * *} \\
(0.137)\end{array}$ & $\begin{array}{c}0.748^{* * *} \\
(0.108)\end{array}$ & $\begin{array}{c}0.770^{* * *} \\
(0.170)\end{array}$ & $\begin{array}{c}0.779^{* * *} \\
(0.138)\end{array}$ & $\begin{array}{c}0.761^{* * *} \\
(0.101)\end{array}$ & $\begin{array}{c}0.764^{* * *} \\
(0.173)\end{array}$ \\
\hline Constant & $\begin{array}{c}0.109 \\
(0.0693)\end{array}$ & $\begin{array}{c}0.184^{* * *} \\
(0.0694)\end{array}$ & $\begin{array}{c}0.0427 \\
(0.0806)\end{array}$ & $\begin{array}{c}0.109 \\
(0.0691)\end{array}$ & $\begin{array}{l}0.178^{* *} \\
(0.0679)\end{array}$ & $\begin{array}{c}0.0435 \\
(0.0815)\end{array}$ \\
\hline Sample & full & $\mathrm{AM}$ & EM & full & $\mathrm{AM}$ & EM \\
\hline Observations & 3,080 & 1,540 & 1,540 & 3,080 & 1,540 & 1,540 \\
\hline R-squared & 0.5147 & 0.5941 & 0.4873 & 0.5147 & 0.5932 & 0.4874 \\
\hline Number of countries & 50 & 23 & 27 & 50 & 23 & 27 \\
\hline
\end{tabular}

Note: Driscoll-Kraay standard errors in parentheses. ${ }^{* * *} \mathrm{p}<0.01 ;^{* *} \mathrm{p}<0.05 ;^{*} \mathrm{p}<0.1$. 
Table 17: Robustness Check: Use the Wu-Xia (2014) Shadow Federal Funds Rate to Address the Issue of Unconventional Monetary Policy at the Zero Lower Bound in the United States

\begin{tabular}{|c|c|c|c|c|c|c|}
\hline Dependent variable: real stock return & (1) & $(2)$ & $(3)$ & $(4)$ & $(5)$ & $(6)$ \\
\hline \multirow[t]{2}{*}{ Expected inflation } & $-1.889^{* * *}$ & $-2.529^{* *}$ & $-1.354^{* * *}$ & $-0.797^{* * *}$ & -2.444 & $-0.874^{* * *}$ \\
\hline & $(0.336)$ & $(0.978)$ & $(0.297)$ & $(0.282)$ & $(1.550)$ & $(0.294)$ \\
\hline \multirow[t]{2}{*}{ Unexpected inflation } & $-1.304^{* *}$ & -2.459 & $-1.232^{* *}$ & -0.965 & -3.111 & $-0.877^{*}$ \\
\hline & $(0.538)$ & $(1.616)$ & $(0.469)$ & $(0.614)$ & $(2.081)$ & $(0.524)$ \\
\hline \multirow[t]{2}{*}{ Expected inflation $\times$ policy rate cyclicality } & $-5.498 * * *$ & $-8.384^{* * *}$ & $-2.386^{* *}$ & & & \\
\hline & $(0.912)$ & $(1.731)$ & $(1.045)$ & & & \\
\hline \multirow[t]{2}{*}{ Unexpected inflation $\times$ policy rate cyclicality } & -0.642 & 2.372 & -0.926 & & & \\
\hline & $(1.318)$ & $(2.729)$ & $(1.419)$ & & & \\
\hline \multirow[t]{2}{*}{ Expected inflation $\times$ countercyclical policy dummy } & & & & $-4.482^{* * *}$ & $-4.461^{* *}$ & $-2.306^{* * *}$ \\
\hline & & & & $(0.700)$ & $(1.745)$ & $(0.754)$ \\
\hline \multirow[t]{2}{*}{ Unexpected inflation $\times$ countercyclical policy dummy } & & & & -1.380 & 2.563 & $-2.207^{* *}$ \\
\hline & & & & $(0.834)$ & $(2.027)$ & $(0.956)$ \\
\hline \multirow[t]{2}{*}{ Industrial production growth rate } & $1.183^{* * *}$ & $0.896^{* * *}$ & $1.419^{* * *}$ & $1.187^{* * *}$ & $0.842^{* * *}$ & $1.434^{* * *}$ \\
\hline & $(0.162)$ & $(0.183)$ & $(0.228)$ & $(0.156)$ & $(0.189)$ & $(0.220)$ \\
\hline \multirow{2}{*}{ M2 growth rate } & $0.402^{* *}$ & 0.0150 & $0.615^{* * *}$ & $0.385^{* *}$ & 0.000615 & $0.602^{* * *}$ \\
\hline & $(0.193)$ & $(0.280)$ & $(0.178)$ & $(0.194)$ & $(0.292)$ & $(0.176)$ \\
\hline \multirow[t]{2}{*}{ Improvement in financial risk rating } & $0.0119^{* *}$ & 0.00109 & $0.0211^{* * *}$ & $0.0117^{* *}$ & 0.00128 & $0.0210 * * *$ \\
\hline & $(0.00468)$ & $(0.00535)$ & $(0.00535)$ & $(0.00470)$ & $(0.00542)$ & $(0.00526)$ \\
\hline \multirow[t]{2}{*}{ Wu-Xia shadow rate } & 0.00682 & $0.0133^{* *}$ & 0.000813 & 0.00756 & $0.0138 * *$ & 0.00123 \\
\hline & $(0.00624)$ & $(0.00647)$ & $(0.00819)$ & $(0.00612)$ & $(0.00673)$ & $(0.00805)$ \\
\hline \multirow[t]{2}{*}{ VIX } & $-0.0164^{* * *}$ & $-0.0169 * * *$ & $-0.0152^{* * *}$ & $-0.0162^{* * *}$ & $-0.0170 * * *$ & $-0.0150 * * *$ \\
\hline & $(0.00284)$ & $(0.00250)$ & $(0.00336)$ & $(0.00286)$ & $(0.00257)$ & $(0.00336)$ \\
\hline \multirow[t]{2}{*}{ Constant } & $0.397^{* * *}$ & $0.471^{* * *}$ & $0.309^{* * *}$ & $0.397^{* * *}$ & $0.468 * * *$ & $0.310 * * *$ \\
\hline & $(0.0703)$ & $(0.0670)$ & $(0.0705)$ & $(0.0682)$ & $(0.0695)$ & $(0.0677)$ \\
\hline Sample & full & $\mathrm{AM}$ & EM & full & $\mathrm{AM}$ & EM \\
\hline Observations & 3,498 & 1,944 & 1,554 & 3,498 & 1,944 & 1,554 \\
\hline R-squared & 0.4041 & 0.4691 & 0.3932 & 0.4058 & 0.4619 & 0.3958 \\
\hline Number of countries & 55 & 27 & 28 & 55 & 27 & 28 \\
\hline
\end{tabular}

